\title{
Water Quality Assessment in the Bamoun Plateau, Western-Cameroon: Hydrogeochemical Modelling and Multivariate Statistical Analysis Approach
}

\author{
Zakari Mfonka1*, Amidou Kpoumié2, Abdou Nasser Ngouh33, Oumar Farouk Mouncherou, \\ Daouda Nsangou, Felaniaina Rakotondrabe5, Alain Fouépé Takounjou4, Mounira Zammouri6, \\ Jules Rémy Ndam Ngoupayou ${ }^{5}$, Paul-Désiré Ndjigui ${ }^{5}$
}

${ }^{1}$ Geosciences, Natural, Resources and Environment Laboratory, Department of Earth Sciences, Faculty of Science, University of Douala, Douala, Cameroon

${ }^{2}$ Geosciences and Sustainable Development Laboratory, Department of Earth Sciences, Faculty of Science, University of Maroua, Maroua, Cameroon

${ }^{3}$ National Institute of Cartography, Ministry of Scientific Research and Innovation, Yaoundé, Cameroon

${ }^{4}$ Institute for Geological and Mining Research, Ministry of Scientific Research and Innovation, Yaoundé, Cameroon

${ }^{5}$ Geosciences of Superficial Formations and Applications Laboratory, Department of Earth Sciences, Faculty of Science, University of Yaoundé I, Yaounde, Cameroon

${ }^{6}$ Center of Water Research and Technologies, Geo-Resources Laboratory, Faculty of Science, University of Tunis El Manar,

Tunis, Tunisia

Email: ${ }^{\star}$ zakarimfonka@yahoo.fr

How to cite this paper: Mfonka, Z., Kpoumié, A., Ngouh, A.N., Mouncherou, O.F. Nsangou, D., Rakotondrabe, F., Takounjou, A.F., Zammouri, M., Ngoupayou, J.R.N. and Ndjigui, P.-D. (2021) Water Quality Assessment in the Bamoun Plateau, WesternCameroon: Hydrogeochemical Modelling and Multivariate Statistical Analysis Approach. Journal of Water Resource and Protection, 13, 112-138.

https://doi.org/10.4236/jwarp.2021.132007

Received: November 8, 2020

Accepted: February 22, 2021

Published: February 25, 2021

\begin{abstract}
This study focuses on the geochemical and bacteriological investigation of surface and ground water in the Bamoun plateau (Western-Cameroon). During the period from September 2013 to August 2014, 71 samples were collected from two springs, one borehole, four wells and the Nchi stream for analysis of major elements. In order to obtain the characteristics of the various species of bacteria, 7 samples were selected. The analytical method adopted for this study is the conventional hydrochemical technic and multivariate statistical analysis, coupled with the hydrogeochemical modelling. The results revealed that, water from the zone under study are acidic to basic, very weakly to weakly mineralized. Four types of water were identified: 1) $\mathrm{CaMg}-\mathrm{HCO}_{3}$; 2) $\left.\mathrm{CaMg}-\mathrm{Cl}-\mathrm{SO}_{4} ; 3\right) \mathrm{NaCl}-\mathrm{SO}_{4}$ and 4) $\mathrm{NaK}-\mathrm{HCO}_{3}$. The major elements were all listed in the World Health Organization guidelines for drinking water quality, except for nitrates which was found at a concentration $>50 \mathrm{mg} \mathrm{NO} \mathrm{NO}_{3}^{-} / \mathrm{l}$ in the borehole F401. As for the hydrobiological aspect, the entire sample contained all the bacteriological species except for spring S301 and well P401.
\end{abstract}


Copyright $\odot 2021$ by author(s) and Scientific Research Publishing Inc. This work is licensed under the Creative Commons Attribution International License (CC BY 4.0).

http://creativecommons.org/licenses/by/4.0/ (c) (i) Open Access
According to the hydrogeochemical modelling, the Gibbs model and multivariate statistical tests, the quality of surface and ground water of the Foumban locality is influenced by two important factors: 1 ) the natural factors characterized by the water-rock interaction, evapotranspiration/crystallization, 2) the anthropogenic factors such as: uncontrolled discharges of liquid and solid effluents of all kinds and without any prior treatment within the ground and the strong urbanization accompanied by lack of sanitation and insufficient care.

\section{Keywords}

Foumban, Surface and Ground Water, Water-Rock Interaction, Bacteriological Parameters, Hierarchical Clustering Analysis, Principal Component Analysis

\section{Introduction}

Water is the main natural resource around the word that humanity needs for its full socio-economic development. This resource is essential to human life in general and households in particular, as well as sectors such as agriculture, breeding, forestry, industry, international trade, tourism and energy [1] [2] [3]. Providing good quality water and in sufficient quantity to African cities in general and Cameroon in particular constitutes a major challenge, not only for the public government, but also for its development partners (United Nation, Global Water Partnership, National Community-Driven Development Programme...). The constraints related to this problem are of several orders, in particular, the insufficient number treatment, storage and distribution infrastructures, as well as the obsolete and degraded nature of the facilities, the poor management and follow-up of the use of water supply structure, often aggravated by severe drought. Another constraint is linked to insufficient nature of hydraulic structures which do not follow the demographic evolution of the regions, the anarchy noted in the real estate construction, making access to water difficult, thus requiring significant additional costs [4] [5].

Despite the abundance of water resources in the Bamoun plateau due to its geographical location and climate, the population's water needs are steadily increasing. However, it constitutes $3 / 4$ of the western region of Cameroon. Statistically, as regards to water access by households for the city of the Foumban which is the most urbanized in the Bamoun plateau [6], there are three types of water highly demanded by the populations.

1) Groundwater (wells, springs and boreholes) which accounts for $72 \%$ water supply to households. Springs are the most used (69\%) followed by wells (22\%) and boreholes (9\%);

2) Camwater which is the national company in charge of collecting, treating and distributing water to the population which supplies about $23 \%$ of populations and finally;

3) Rainwater which accounts for $10 \%$ of water supply to households in the 
rainy season.

In the Foumban locality and the Bamoun plateau in general, groundwater is highly used by the population. Their reason is that this water has good quality (clear and transparent). It has very little or almost unknown physicochemical and bacteriological characteristics. In fact, most of the scientific researches carried out in this area and its surroundings were mostly focused on the petrology, petrography and hydrogeology aspects [7] [8] [9]. They did not take into account the quality aspect of water consumption in that zone. The aim of this study was to assess the water quality of surface and ground water of the Bamoun plateau, specifically in the Foumban locality. It was conducted during the period from September 2013 to October 2014 and applied the hydro-geochemical modelling techniques and multivariate statistical analysis. This method has been used by many authors in geology, and has produced satisfactory results [1] [10] [11]. The first assess the impact of the mining activities in the Bétaré-Oya locality, the second present the variability of geotechnical parameters of lateritic gravels overlying contrasted metamorphic rocks in a tropical humid area in Cameroon and the third characterize the groundwater quality using hydrochemical and statistical approaches in the shallow aquifer of Mahdia-Ksour Essaf in Tunisia.

\section{Materials and Methods}

\subsection{Description of the Study Area}

\subsubsection{Geographical and Geomorphological Sitting}

The Foumban locality is situated in the West region of Cameroon. Based on its geomorphological aspect, it is found within the Bamoun Plateau with altitudes ranging between 932 and $2269 \mathrm{~m}$ a.s.l. (Figure 1) and drained by several streams that flow into the Mbam River. According to [6] [9] [12], the Mbam river (42,300 $\left.\mathrm{km}^{2}\right)$ is the largest collector on the right bank of the Sanaga river $\left(133,000 \mathrm{~km}^{2}\right.$ and $920 \mathrm{~km}$ long), the largest and most important river in Cameroon. The climate is of the tropical humid mountain type with two contrasting seasons consisting of a long rainy season of 9 months (April to November) and a short dry season of 3 months (December to February). The average annual rainfall and temperature are about $1855 \pm 203 \mathrm{~mm}$ and $21^{\circ} \mathrm{C}$, respectively, with vegetation consisting of woody savannah.

\subsubsection{Geological and Hydrogeological Context}

The study area and its surroundings are based on Precambrian crystalline-crystallophyllian bedrock [7] [13] [14] [15]. This substratum is composed of plutonic (anatexic and syntectonic granite) and/or metamorphic (orthogneiss, mylonite, biotite, and amphibole gneiss) rocks on which volcanic outflows consisting mostly of plateau basalts are formed [14] (Figure 2). These are the so-called transitional basalts (olivine and olivine-free basalts) with presence of local rhyolites, rhyolite tuffs, and andesites [7] [14].

As for the hydrogeology, the previous studies made in this domain [6] [9] [16], coupled with those conducted in the same environments in Cameroon and 


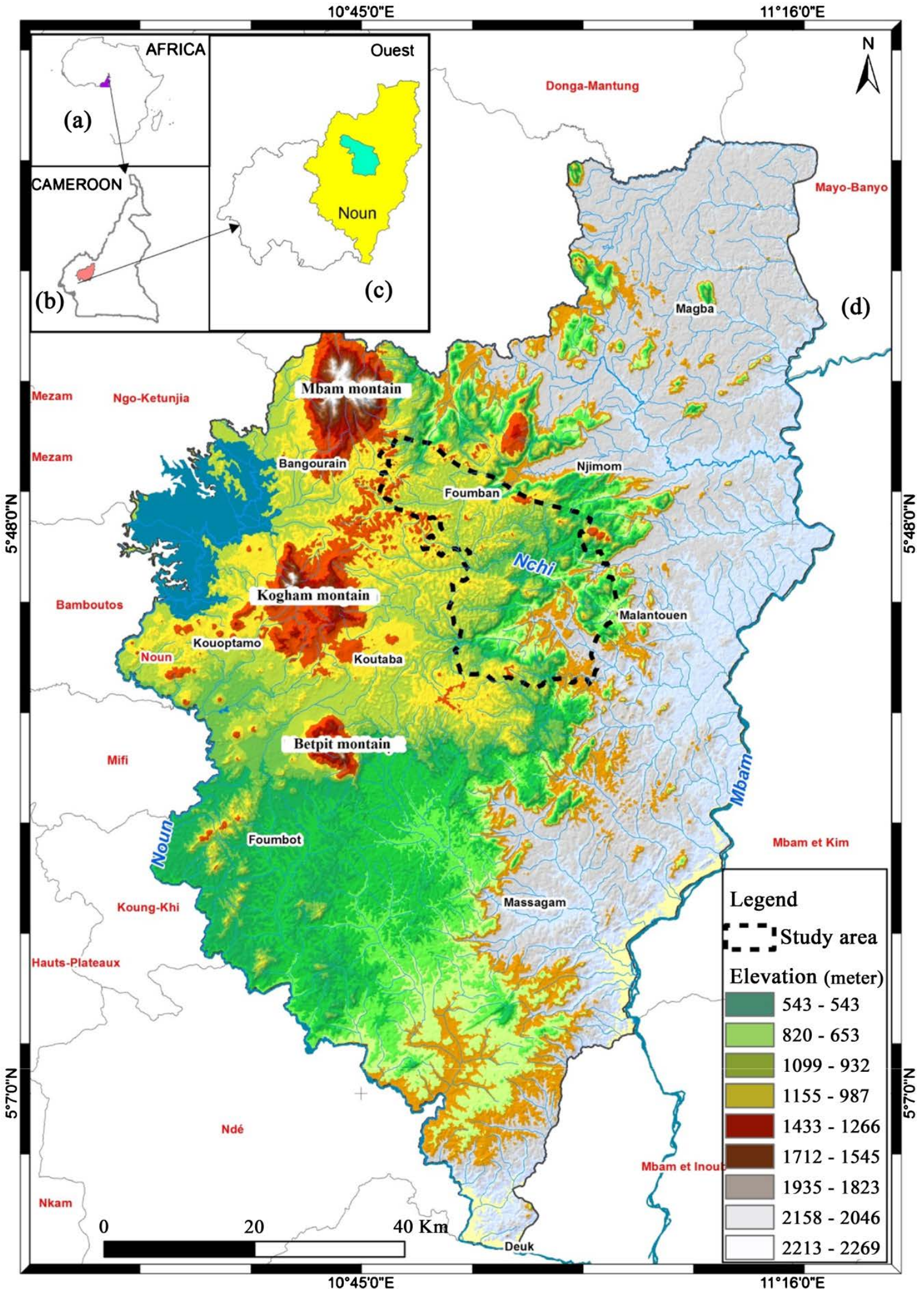

Figure 1. Location of the study area (a) Cameroon in Central Africa; (b) West region of Cameroon; (c) Foumban locality in the West region; (d) Foumban locality in the Bamoun Plateau (Mfonka et al. 2019). 


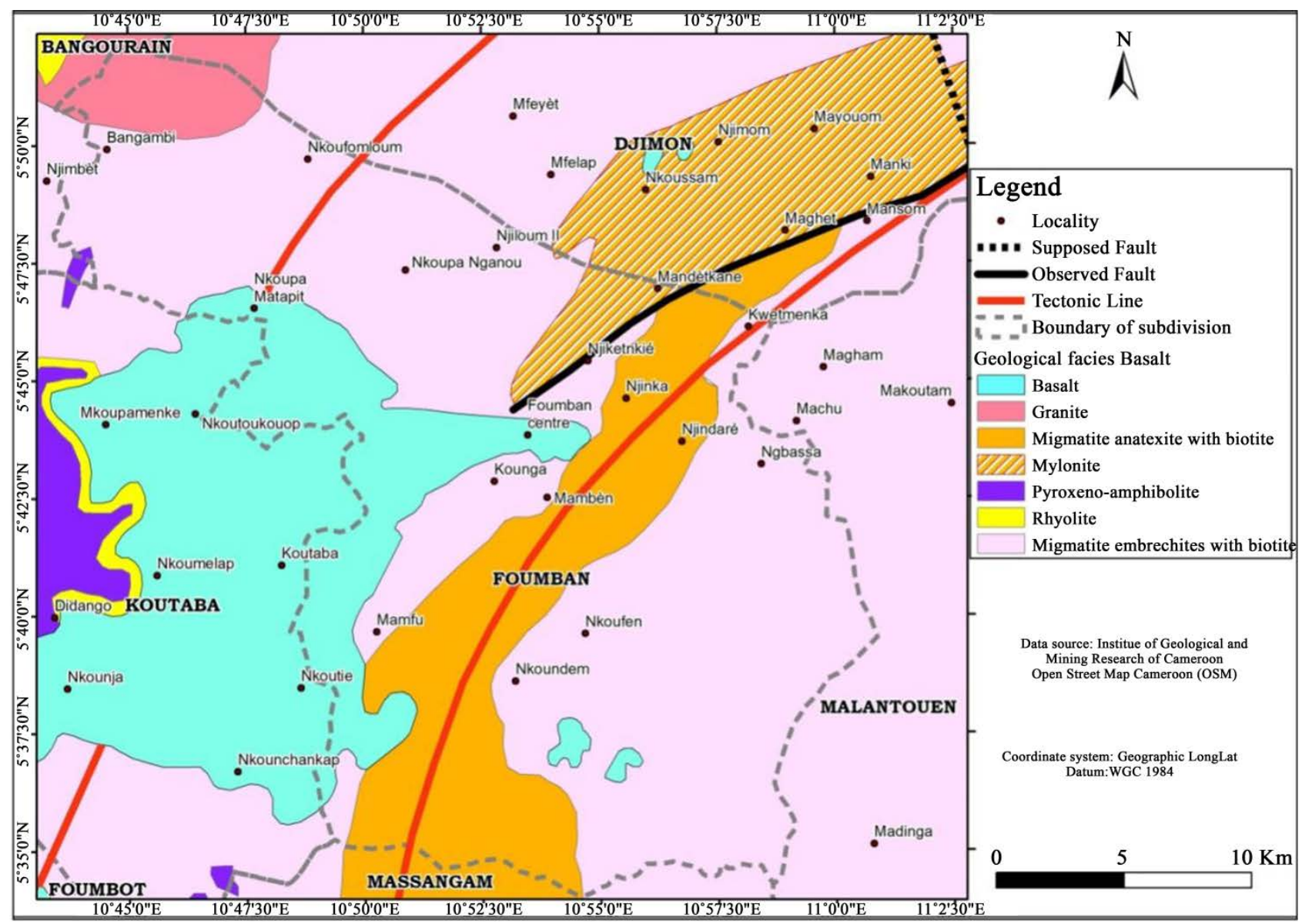

Figure 2. Geological map of the Foumban locality and its surroundings.

elsewhere around the world, [17] [18] show that:

- the Foumban locality has two types of underlying aquifers that function as a bi-layer system: an upper continuous aquifer (unconfined aquifer) developed on the saprolite, generally used for wells and boreholes. The discontinuous fissured aquifers (confined aquifer) of the basement are used for boreholes only.

- the relationship between the topography and the piezometric surface shows that the piezometry clearly follows the shape of the landscape of the study area. The dome is observed under the plateau and depressions in the valleys. These piezometric domes located in high-altitude zones also constitute the ground water divide. The piezometric variations generally follow those of rains. These reactions are thus related to the physical and hydrodynamic characteristics of the aquifer such as the hydraulic conductivity, the impact of the vadose zone, the storage capacity of the piezometers, the local structure of the aquifer, the initial state of the water table, but also and above all, the topography.

- the hydrogeological modelling carried out by [16] and some other authors in the basement milieu [18] [19] [20] [21] show that the aquifer systems in the basement milieu are so complex, discontinuous and heterogeneous. 


\subsection{Method}

Within the framework of this study, three elementary basins, representative of the Bamoun plateau have been identified and chosen in the city of Foumban.They are, from East to West, Lompit, Ngâ and Mfomchout watersheds whose physical, hydrodynamics, human and socio-environmental characteristics are presented in Table 1. The selection criteria used for these sites were: the presence of many hydraulic facilities in the zone for water supply (wells, boreholes and springs), the water needs of the populations for domestic, agricultural, pastures, and other uses, the standard of living of the populations found within these three watersheds.

\subsubsection{Sampling and Analytical Procedure}

Height (08) of drinking water points were identified in the study zone using Global Positioning System (GPS) materialized on an Advanced Spaceborne Thermal Emission and Reflection Radiometer (ASTER) satellite image with a $30 \mathrm{~m}$ resolution, particularly for four shallow wells (P102, P314, P401 and P501), two springs (S301 and S401), one borehole (F401) and the Nchi stream (Figure 3). Those points were selected based on criteria such as: the request by the population for water consumption, the accessibility, and their representativeness in the study area. Ten (10) sampling campaigns were carried out on a monthly basis and covering the 2013-2014 hydrological year, except for F401, P102 and P401 sampling points where only 6,7 and 8 sampling campaigns respectively were conducted. This is due to the faulty state of the pumping system of those sampling

Table 1. Characteristics of the Mfomchout, Nga, and Lompit basins in the Foumban locality (Mfonka et al. 2019).

\begin{tabular}{|c|c|c|c|}
\hline Characteristic of watershed & Mfomchout & Ngâ & Lompit \\
\hline Latitude & $5^{\circ} 43^{\prime} 45^{\prime \prime}$ and $5^{\circ} 44^{\prime} 58^{\prime \prime}$ & $5^{\circ} 43^{\prime} 45^{\prime \prime}$ and $5^{\circ} 44^{\prime} 40^{\prime \prime}$ & $5^{\circ} 43^{\prime} 42^{\prime \prime}$ and $5^{\circ} 44^{\prime} 40^{\prime \prime}$ \\
\hline Longitude & $10^{\circ} 52^{\prime} 25^{\prime \prime}$ and $10^{\circ} 53^{\prime} 00^{\prime \prime}$ & $10^{\circ} 53^{\prime} 00^{\prime \prime}$ and $10^{\circ} 53^{\prime} 30^{\prime \prime}$ & $10^{\circ} 53^{\prime} 30^{\prime \prime}$ and $10^{\circ} 54^{\prime} 10^{\prime}$ \\
\hline Surface area $\left(\mathrm{m}^{2}\right)$ & 1.387 & 0.942 & 1.16 \\
\hline Perimeter $(\mathrm{m})$ & 5.315 & 3.974 & 5.578 \\
\hline Coefficient of Gravelius & 1.2 & 1.15 & 1.45 \\
\hline Form of the basin & Rectangle & Rectangle & rectangle \\
\hline Equivalent length (m) & 1.97 & 1.24 & 2.304 \\
\hline Equivalent width $(\mathrm{m})$ & 0.703 & 0.759 & 0.504 \\
\hline Minimal altitude (m) & 1075 & 1033.5 & 1033.5 \\
\hline Maximal altitude (m) & 1231.5 & 1225 & 1225 \\
\hline Median altitude (m) & 1112.5 & 1137.5 & 1137.5 \\
\hline Order of the river & 4 & 4 & 4 \\
\hline Geology & Basalt & Basalt & Basalt \\
\hline Type of residential building & Modern & Spontaneous habitats & Mixed habitat \\
\hline Type of cleaning up & Modern & Traditional & Mixed \\
\hline
\end{tabular}




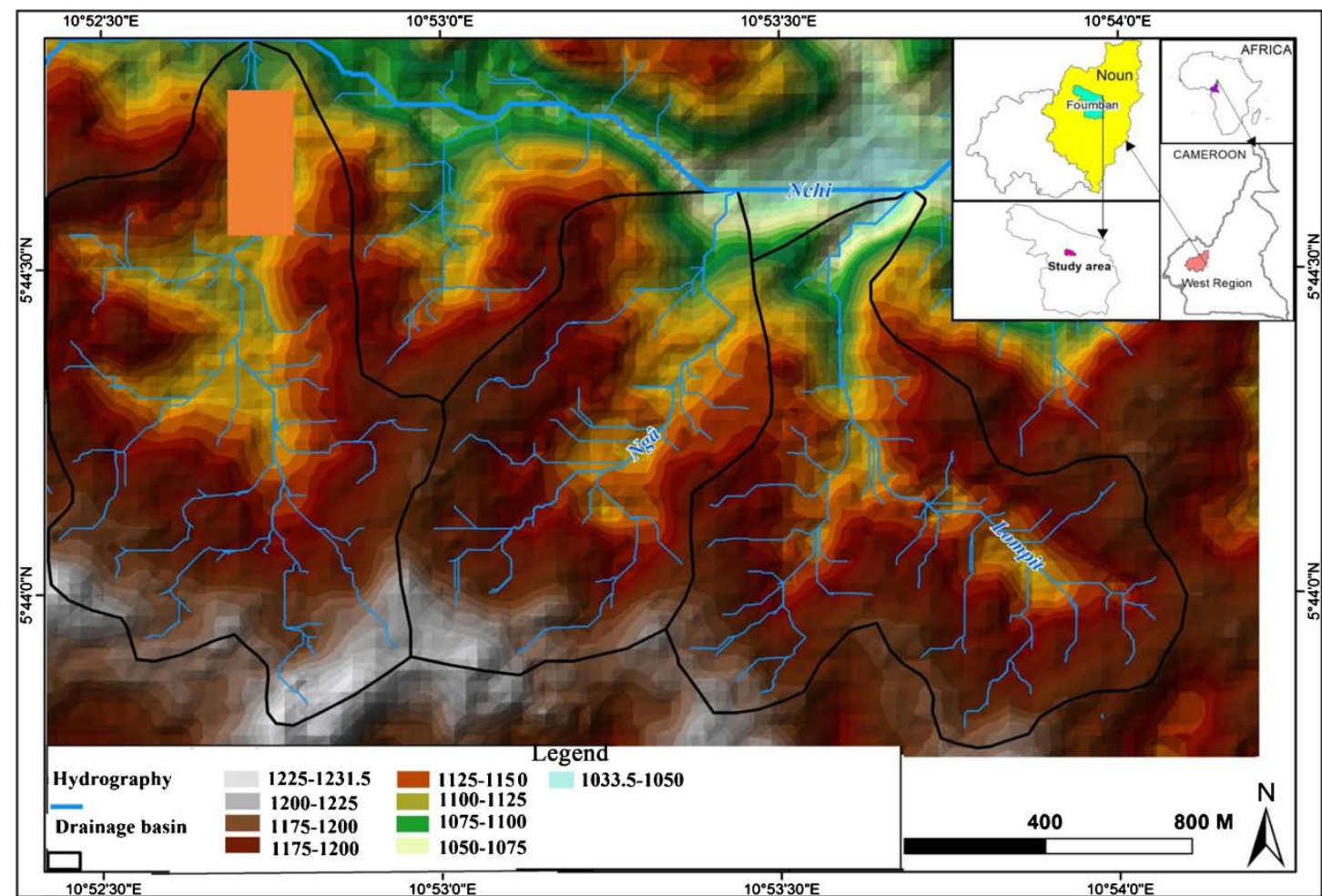

(a)

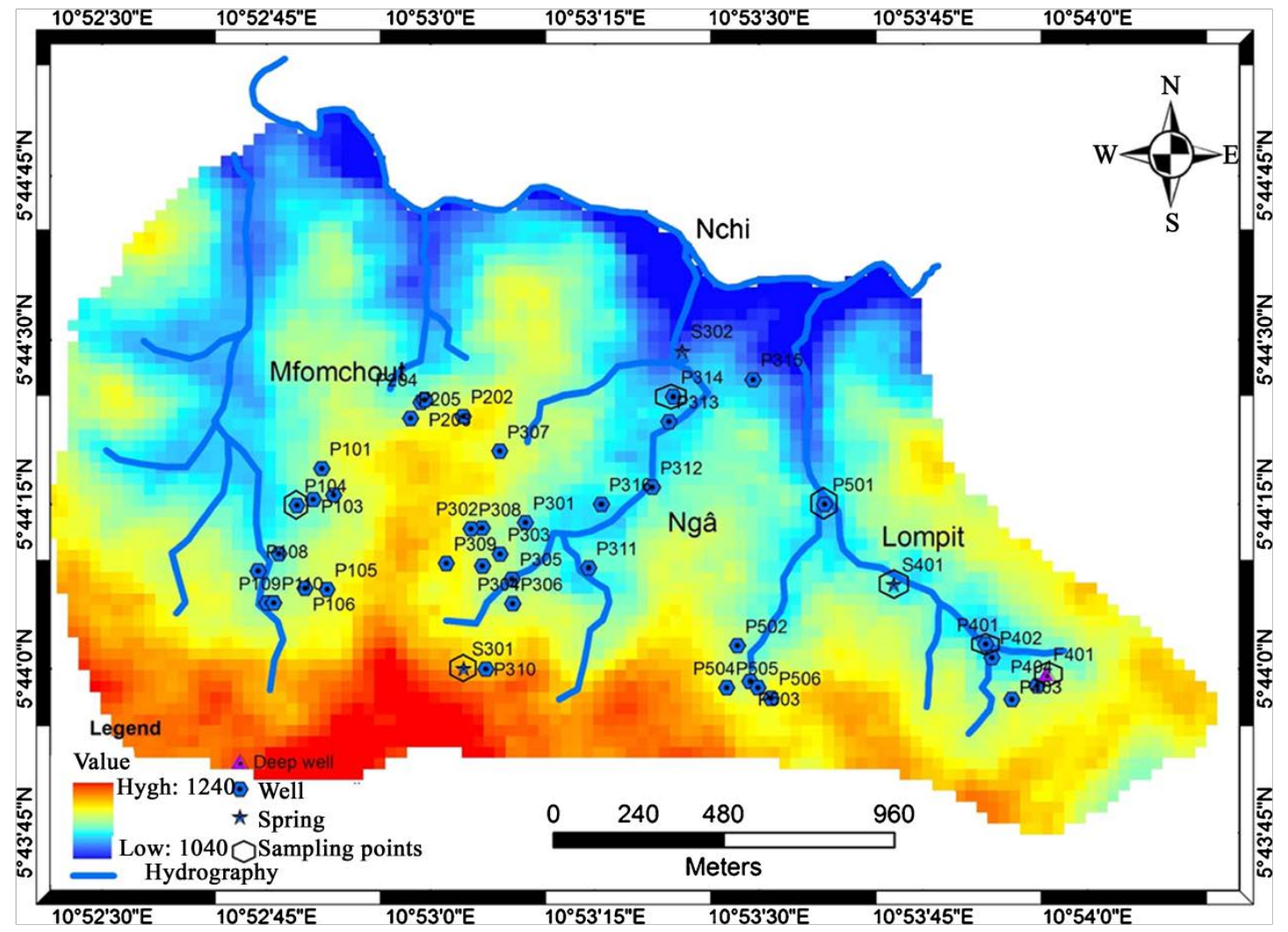

(b)

Figure 3. Location of the Mfomchout, Ngâ and Lompit watersheds with their hypsometric characteristics in the Foumban locality (a) and the sampling points (b). 
sites. A total of seventy-one (71) water samples were collected in 1.51 polyethylene bottles that had previously been washed with ultrapure acid and rinsed with distilled water and then with MilliQ deionized water for chemical analysis. Before a sample was collected, the bottle was rinsed three times with the water to be used as sample, in accordance with standard procedures [22] [23] [24] [25] [26]. The analyses were performed in the Geochemical Laboratory in Yaoundé (Cameroon) using High Performance Liquid Chromatography (HPLC). The other water samples were filtered with cellulose acetate $0.45 \mu \mathrm{m}$ membranes using a polycarbonate millipore filtration unit. The major cations $\left(\mathrm{Na}^{+}, \mathrm{NH}_{4}^{+}, \mathrm{K}^{+}, \mathrm{Mg}^{2+}\right.$, $\mathrm{Ca}^{2+}$ ) were assayed by Dionex ICS-90 ion chromatography (error $\leq 5 \%$ ) and the major anions $\left(\mathrm{HCO}_{3}^{-}, \mathrm{Cl}^{-}, \mathrm{F}^{-}, \mathrm{NO}_{3}^{-}, \mathrm{PO}_{4}^{3-}, \mathrm{SO}_{4}^{2-}\right)$ by Dionex ICS-1100 ion chromatography (precision $= \pm 5 \%-10 \%$ ). Alkalinity was measured by automatic titration in an 862 Compact Metrohm model. Ultrapure water (MQ) with a resistivity of $18.2 \mathrm{M} \Omega \cdot \mathrm{cm}$ was used for all analyses and was also used as a blank. Each calibration curve was assessed by analyzing the quality control standards before, during and after analyzing a set of samples. The parameters such as: PHs, $\mathrm{T}^{\circ} \mathrm{C}$, electrical conductivity (EC) was measured on unfiltered water in the field, using calibrated WTW $315 \mathrm{i}$ multi-parameters instrument.

As for what concerns the samples destined for bacteriological analyses (FC, FS and $E$. coli), except for surface water, the same structures were used for analyses. Faecal coliform (CF), faecal streptococci (FS) Escherichia coli that are indicators of water pollution have been analysed respectively by using colorimetric methods on filtering membrane, by cellulose membrane filtration and the application of the latter on a nutritive medium and finally the seeding in an agar medium containing a chromogeneous or fluorogeneous substrate. These methods have already been described in the literature [22] [27] [28]. These analyses were done in the Wastewater Research Unit laboratory of the Department of Plan Biology of the University of Yaoundé I. The analytical results of the bacteriological parameters are expressed as Colony Forming Unit per unit volume of $100 \mathrm{ml}$ based on Equation (1) below:

$$
\mathrm{CFU}=\frac{\mathrm{NCC}}{\mathrm{QSF}(\mathrm{ml})} \times 100 \mathrm{ml}
$$

$$
\begin{aligned}
& \mathrm{CFU}=\text { Colony Forming Unit, } \\
& \mathrm{NCC}=\text { Number of Colonies counted, } \\
& \mathrm{QSF}=\text { Quantity of sample filtered. }
\end{aligned}
$$

\subsubsection{Inverse Geochemical Modelling}

Saturation indices (SI) are important to determine the reactivity of minerals in water resources [29]; they were calculated using the Phreeqc programme incorporated in the Diagram software. According to [29] [30], when SI is less than zero, the solution is considered under saturated; when SI is equal to zero, the solution is saturated and equilibrium is achieved between mineral dissolution and precipitation. When SI is upper than zero, the solution is oversaturated and 
extra minerals precipitate. This index is calculated using the following formula:

$$
\mathrm{SI}=\log \mathrm{IAP} / \mathrm{Kt}
$$

where, SI is the saturation indices, IAP, the ion activity product of the dissociated chemical species in solution and $K t$ the equilibrium solubility product of the mineral.

\subsubsection{Multivariate Statistical Analysis (MSA)}

Multivariate statistical analysis broadly refers to the various statistical techniques that can be used to analyse two or more variables simultaneously, and it is difficult to analyse multivariate data containing several variables [24] [26] [28] [31] [32] [33]. In this study, three multivariate statistical procedures were used to obtain a better understanding of the variety in the data set and the processes involved. The statistical package used was XLSTAT 2007, and the analyses included correlation matrix, principal components and hierarchical cluster analysis. MSA was performed on 71 water samples of surface and ground water alongside all of the following variable: $\mathrm{pH}, \mathrm{T}^{\circ}, \mathrm{CE}, \mathrm{K}^{+}, \mathrm{Na}^{+}, \mathrm{Ca}^{2+}, \mathrm{Mg}^{2+}, \mathrm{NO}_{3}^{-}, \mathrm{SO}_{4}^{3-}$, $\mathrm{Cl}^{-}, \mathrm{F}^{-}, \mathrm{HCO}_{3}^{-}$, Alk, and $\mathrm{PO}_{4}^{-}$, and three bacteriological parameters as well as FC, FS et $E$. coli.

\section{1) Correlation matrix}

The correlation coefficient matrix measures how well the variance of each constituent can be explained in relationships with each other [34]. The terms "strong", "moderate", and "weak" were used to factor loadings and refer to absolute loading values as $>0.75,0.75-0.50$, and $0.50-0.30$, respectively, following the approach of [16]. The strong value of correlation matrix is 0.77 given by the Pearson's correlation coefficient type. This type of correlation theory was used because it is better adapted to continuous and Gaussian data quality, contrary to the Spearman and Kendall type which are better for ordinal variables [31] [35].

\section{2) Principal components analysis (PCA)}

PCA is the multivariate statistical technique that is used to reduce data and decipher patterns within large sets of data. It is the method widely used in geology [10] [26] [28] [36]. Data reduction is performed by transforming data to a new set of variables (principal components) that are derived from linear combinations of the original variables and classified in such a way that the first principal components (typically two or three) are responsible for most of the variation in the original dataset [35] [37] [38] [39].

3) Hierarchical cluster analysis (HCA)

Cluster analysis provided by the dendrogram is a family of multivariate techniques designed to uncover and classify naturally occurring subgroups within a dataset based on similarities between the observations. HCA seeks to build a hierarchy of clusters and can also be applied to compositional data that are logtransformed [24].

\section{4) Hydro-chemical modelling using Gibbs approach}

In addition to the multivariate statistical analysis method, the Gibbs model 
[40] was used to understand the phenomena that govern water quality of the study area. The Gibbs model defined the mechanisms that control the chemical characteristics of world water as three end-members: atmospheric precipitation, rock dominance, and the evaporation-crystallisation process on the basis of analysing numerous rain, river, lake, and ocean samples. To identify the contribution of the three end-members, TDS versus $\mathrm{Na} /(\mathrm{Na}+\mathrm{Ca})$ or TDS versus $\mathrm{Cl} /(\mathrm{Cl}$ $+\mathrm{HCO}_{3}$ ) are used.

\section{Results and discussions}

\subsection{General Physico-Chemical Characteristics of Ground Water and Surface Water in the Foumban Locality}

Physicochemical parameters of the surface and ground water of the Foumban locality are summarized in Figure 4. During the study period, the $\mathrm{pH}$ values varied from 4.50 to 8.48 with an average value of $6.33 \pm 0.66$, indicating that there is a range of acidic to basic characteristics. The Electrical Conductivity (EC) was very low, ranging between 8.40 and $398.00 \mu \mathrm{S} / \mathrm{cm}$ with a mean value of $102.99 \pm 77.27 \mu \mathrm{S} / \mathrm{cm}$. This type of water is very weakly to weakly mineralized [41], like most of the water in the woody savannah and forested parts of western and southern Cameroon respectively, which flows on a plutono-metamorphic basement [1] [42], contrary to water in the sedimentary milieu which are very mineralized. Regarding temperatures, they range from 20.70 and 28.20 for an average of $23.75^{\circ} \mathrm{C} \pm 1.53^{\circ} \mathrm{C}$, The sum of the cations equivalents ranges from 31.23 and 1812.64 for an average of $628.13 \pm 554.53 \mu \mathrm{eq} / \mathrm{l}$. As for the sum of anions equivalents, they fluctuate between 18.63 et 1778.19 for an average of $603.65 \pm 481 \mu \mathrm{eq} / \mathrm{l}$. Nitrates that are pollution indicators have concentrations that peak at $1169 \pm 314 \mu \mathrm{eq} / \mathrm{l}$, higher than World Health Organisation (WHO) standards $(50 \mathrm{mg} / \mathrm{l})$ for water destined for human consumption.

\subsection{Hydrogeochemical Modelling}

\subsubsection{Water Type}

Hydro-geochemical classification done by using Piper trilinear diagram [43] (Figure 5) revealed the presence of four water types in the study sites: 1) CaMg-

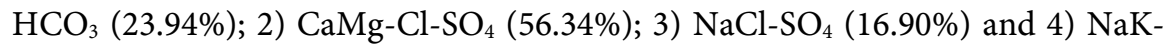
$\mathrm{HCO}_{3}(2.81 \%)$. It should be noted that these types slightly changed for some works by one month or from one season to another during the hydrological year. It is the case with wells $\mathrm{P} 102, \mathrm{P} 401, \mathrm{~S} 401$ and the Nchi stream. The CaMg-Cl-SO $\mathrm{S}_{4}$ and $\mathrm{NaCl}-\mathrm{SO}_{4}$ type classes suggest water contamination in this area as a result of anthropogenic factors. The chlorides and nitrates probably originate from urban waste.

\subsubsection{Saturation Indices (SI)}

The thermodynamic equilibrium results of SI are presented in Table 2. All the water samples of the study site are slightly to weakly under saturated with Aragonite, Anhydrite, Calcite, Dolomite, and Gypsum, but was strongly under saturated 

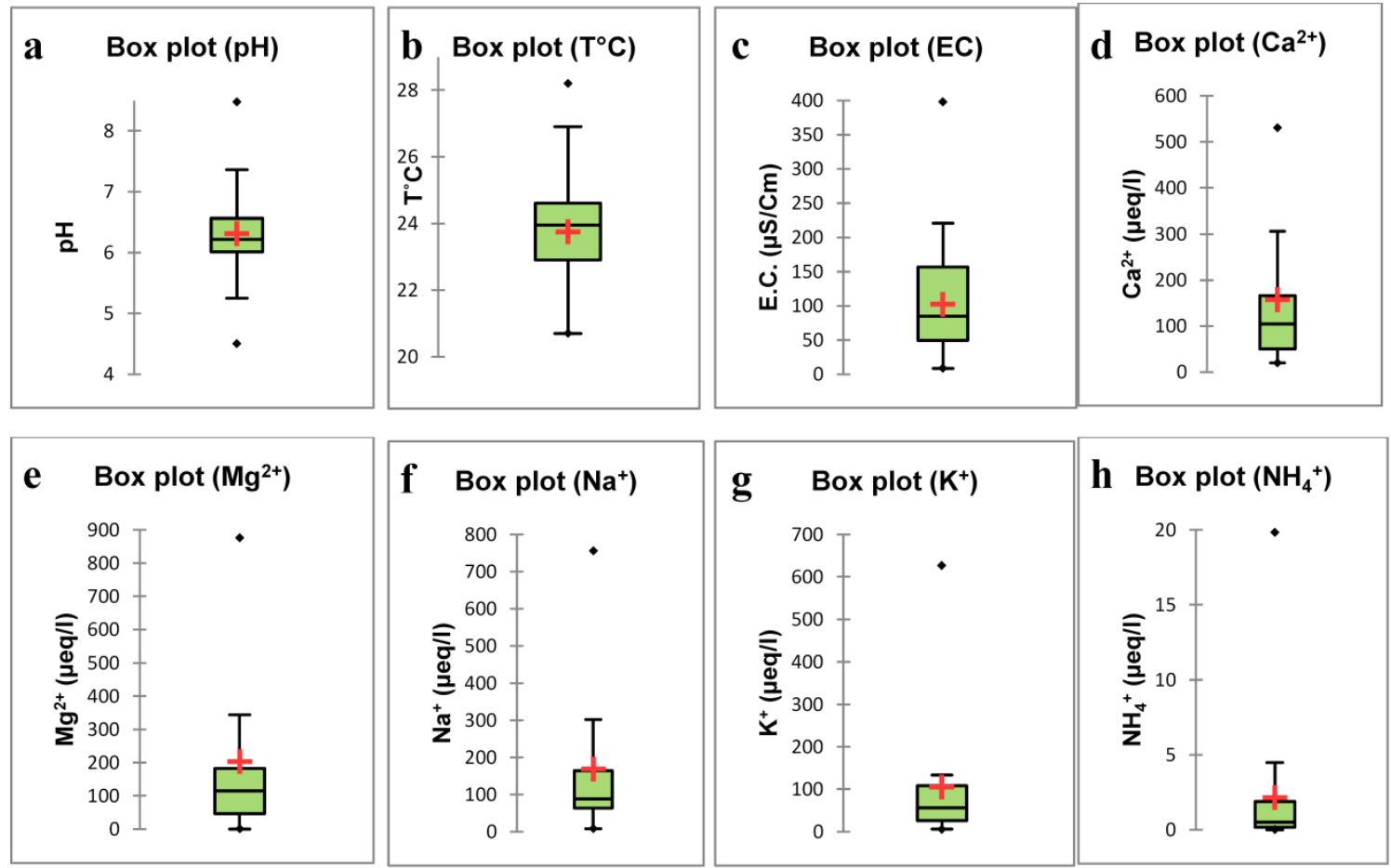

f $\operatorname{Box}$ plot $\left(\mathrm{Na}^{+}\right)$

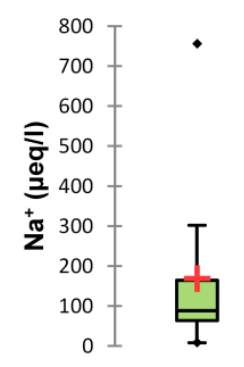

i Box plot (Alc)

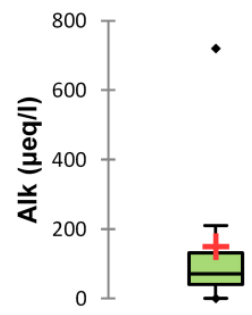

j Box plot $\left(\mathrm{HCO}_{3}{ }^{-}\right)$

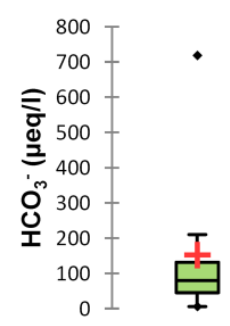

g Box plot $\left(\mathrm{K}^{+}\right)$

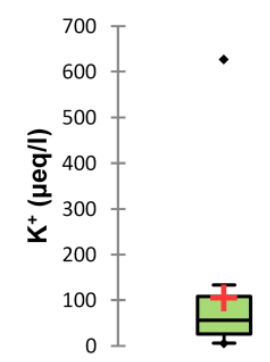

h Box plot $\left(\mathrm{NH}_{4}{ }^{+}\right)$

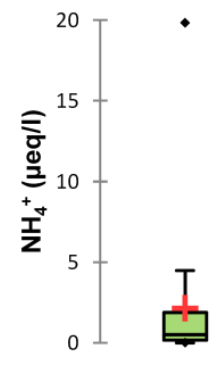

m Box plot $\left(\mathrm{PO}_{4}{ }^{3-}\right)$

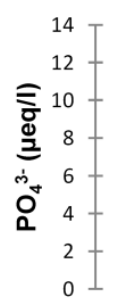

n Box plot $\left(\mathrm{SO}_{4}{ }^{2-}\right)$

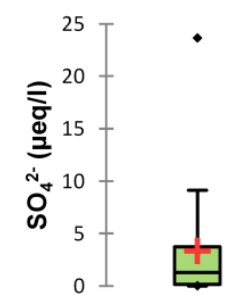

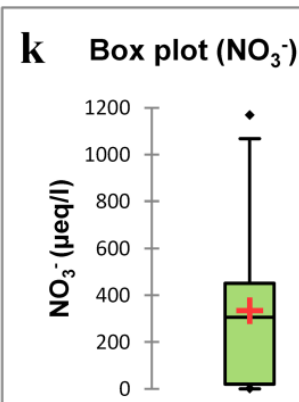

I Box plot (Cl-)

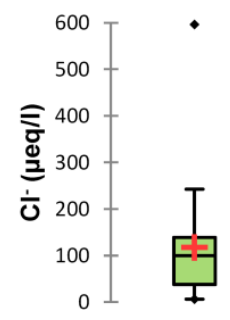

q Box plot ( $\left.\mathrm{TZ}^{+}\right)$

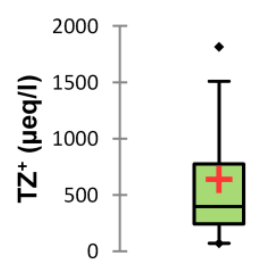

Figure 4. Geochemical characteristics of the analysed samples in the study sites. 
Table 2. Statistic values of SI of the surface and groundwater in the Foumban locality, Bamoun Plateau.

\begin{tabular}{|c|c|c|c|c|c|c|c|c|c|c|}
\hline Name [phreeqc. dat] & Anhydrite & Aragonite & Calcite & Dolomite & Gypsum & $\mathrm{H}_{2}(\mathrm{~g})$ & $\mathrm{H}_{2} \mathrm{O}(\mathrm{g})$ & $\mathrm{O}_{2}(\mathrm{~g})$ & Halite & $\mathrm{CO}_{2}(\mathrm{~g})$ \\
\hline \multicolumn{11}{|l|}{ Nchi River } \\
\hline Min & -4.74 & -2.68 & -2.54 & -4.87 & -4.52 & -24.96 & -1.51 & -43.52 & -8.07 & -2.97 \\
\hline Max & -2.61 & 0.90 & 1.04 & 2.30 & -2.39 & -19.80 & -1.51 & -33.20 & -7.14 & -1.29 \\
\hline Mean & -3.57 & -1.26 & -1.12 & -2.03 & -3.35 & -21.36 & -1.51 & -40.41 & -7.65 & -1.66 \\
\hline Med & -3.53 & -1.26 & -1.12 & -2.04 & -3.31 & -21.20 & -1.51 & -40.72 & -7.69 & -1.52 \\
\hline SD & 0.57 & 0.94 & 0.93 & 1.88 & 0.57 & 1.37 & 0.00 & 2.74 & 0.29 & 0.47 \\
\hline $\mathrm{CV}$ & -16.04 & -74.05 & -83.61 & -92.71 & -17.10 & -6.41 & 0.00 & -6.78 & -3.84 & -28.58 \\
\hline $\mathrm{N}$ & 10 & 10 & 10 & 10 & 10 & 10 & 10 & 10 & 10 & 100 \\
\hline \multicolumn{11}{|l|}{ F401 } \\
\hline Min & -2.67 & -2.78 & -2.63 & -5.24 & -2.45 & -20.40 & -1.51 & -46.44 & -5.32 & -1.63 \\
\hline $\operatorname{Max}$ & -2.50 & -1.39 & -1.25 & -2.16 & -2.28 & -18.34 & -1.51 & -42.32 & -5.07 & -0.45 \\
\hline Mean & -2.59 & -2.04 & -1.90 & -3.71 & -2.37 & -19.36 & -1.51 & -44.40 & -5.19 & -1.06 \\
\hline Med & -2.59 & -2.03 & -1.89 & -3.75 & -2.37 & -19.31 & -1.51 & -44.50 & -5.18 & -0.99 \\
\hline $\mathrm{SD}$ & 0.12 & 0.64 & 0.64 & 1.35 & 0.12 & 0.92 & 0.00 & 1.84 & 0.09 & 0.42 \\
\hline $\mathrm{CV}$ & -4.65 & -31.29 & -33.63 & -36.44 & -5.08 & -4.75 & 0.00 & -4.14 & -1.69 & -39.48 \\
\hline $\mathrm{N}$ & 6 & 6 & 6 & 6 & 6 & 6 & 6 & 6 & 6 & 6 \\
\hline \multicolumn{11}{|l|}{ P501 } \\
\hline Min & -4.94 & -2.16 & -2.01 & -3.89 & -4.72 & -21.20 & -1.51 & -43.92 & -6.53 & -1.67 \\
\hline Max & -2.66 & -1.34 & -1.20 & -2.25 & -2.44 & -19.60 & -1.51 & -40.72 & -5.80 & -0.91 \\
\hline Mean & -3.74 & -1.72 & -1.58 & -2.99 & -3.52 & -20.17 & -1.51 & -42.77 & -6.02 & -1.30 \\
\hline Med & -3.71 & -1.62 & -1.48 & -2.85 & -3.49 & -20.17 & -1.51 & -42.78 & -5.95 & -1.27 \\
\hline SD & 0.73 & 0.32 & 0.32 & 0.59 & 0.73 & 0.55 & 0.00 & 1.11 & 0.25 & 0.24 \\
\hline $\mathrm{CV}$ & -19.51 & -18.59 & -20.23 & -19.62 & -20.73 & -2.75 & 0.00 & -2.59 & -4.21 & -18.59 \\
\hline $\mathrm{N}$ & 10 & 10 & 10 & 10 & 10 & 10 & 10 & 10 & 10 & 10 \\
\hline \multicolumn{11}{|l|}{ S301 } \\
\hline Min & -4.12 & 0.54 & 0.68 & 1.95 & -3.90 & -23.00 & -1.51 & -38.00 & -7.33 & -1.95 \\
\hline Max & -2.97 & 0.96 & 1.11 & 2.81 & -2.75 & -22.56 & -1.51 & -37.12 & -6.60 & -1.64 \\
\hline Mean & -3.43 & 0.82 & 0.96 & 2.51 & -3.21 & -22.72 & -1.51 & -37.68 & -6.84 & -1.76 \\
\hline Med & -3.46 & 0.86 & 1.00 & 2.57 & -3.24 & -22.68 & -1.51 & -37.76 & -6.79 & -1.76 \\
\hline SD & 0.38 & 0.12 & 0.12 & 0.25 & 0.38 & 0.14 & 0.00 & 0.28 & 0.24 & 0.10 \\
\hline $\mathrm{CV}$ & -11.01 & 14.97 & 12.95 & 9.85 & -11.77 & -0.63 & 0.00 & -0.75 & -3.50 & -5.79 \\
\hline $\mathrm{N}$ & 10 & 10 & 10 & 10 & 10 & 10 & 10 & 10 & 10 & 10 \\
\hline \multicolumn{11}{|l|}{ S401 } \\
\hline Min & -5.47 & -2.31 & -2.17 & -3.66 & -5.25 & -22.72 & -1.51 & -42.84 & -7.18 & -1.91 \\
\hline Max & -2.62 & 0.26 & 0.41 & 1.31 & -2.40 & -20.14 & -1.51 & -37.68 & -6.90 & -1.06 \\
\hline Mean & -4.28 & -1.52 & -1.38 & -2.23 & -4.06 & -20.72 & -1.51 & -41.68 & -7.03 & -1.54 \\
\hline
\end{tabular}




\section{Continued}

\begin{tabular}{|c|c|c|c|c|c|c|c|c|c|c|}
\hline Med & -4.55 & -1.61 & -1.47 & -2.42 & -4.33 & -20.48 & -1.51 & -42.16 & -7.02 & -1.62 \\
\hline SD & 1.09 & 0.72 & 0.73 & 1.43 & 1.09 & 0.79 & 0.00 & 1.58 & 0.08 & 0.27 \\
\hline $\mathrm{CV}$ & -25.47 & -47.65 & -52.83 & -64.12 & -26.87 & -3.81 & 0.00 & -3.79 & -1.19 & -17.80 \\
\hline $\mathrm{N}$ & 10 & 10 & 10 & 10 & 10 & 10 & 10 & 10 & 10 & 10 \\
\hline \multicolumn{11}{|l|}{ P102 } \\
\hline Min & -5.16 & -3.45 & -3.31 & -6.14 & -4.94 & -20.54 & -1.51 & -43.72 & -8.68 & -2.12 \\
\hline $\operatorname{Max}$ & -3.54 & -2.01 & -1.87 & -3.35 & -3.32 & -19.70 & -1.51 & -42.04 & -7.54 & -1.32 \\
\hline Mean & -4.36 & -2.85 & -2.71 & -4.96 & -4.14 & -20.01 & -1.51 & -43.11 & -8.18 & -1.74 \\
\hline Med & -4.35 & -2.77 & -2.63 & -4.88 & -4.13 & -19.88 & -1.51 & -43.36 & -8.27 & -1.75 \\
\hline SD & 0.60 & 0.47 & 0.47 & 0.90 & 0.60 & 0.34 & 0.00 & 0.67 & 0.44 & 0.33 \\
\hline $\mathrm{CV}$ & -13.69 & -16.68 & -17.54 & -18.16 & -14.42 & -1.68 & 0.00 & -1.56 & -5.40 & -18.78 \\
\hline $\mathrm{N}$ & 7 & 7 & 7 & 7 & 7 & 7 & 7 & 7 & 7 & 7 \\
\hline \multicolumn{11}{|l|}{ P314 } \\
\hline Min & -5.18 & -3.31 & -3.16 & -5.74 & -4.96 & -20.52 & -1.51 & -48.20 & -7.05 & -2.17 \\
\hline Max & -2.71 & -1.39 & -1.25 & -1.62 & -2.49 & -17.00 & -1.51 & 649.12 & -5.83 & 0.22 \\
\hline Mean & -3.94 & -2.04 & -1.90 & -3.11 & -3.63 & -19.57 & -1.51 & 25.85 & -6.40 & -1.03 \\
\hline Med & -3.90 & -1.84 & -1.69 & -2.87 & -3.68 & -20.12 & -1.51 & -42.68 & -6.41 & -1.13 \\
\hline SD & 0.77 & 0.60 & 0.60 & 1.31 & 0.84 & 1.28 & 0.00 & 219.00 & 0.35 & 0.76 \\
\hline $\mathrm{CV}$ & -19.45 & -29.32 & -31.42 & -42.21 & -23.00 & -6.53 & 0.00 & 847.27 & -5.41 & -74.11 \\
\hline $\mathrm{N}$ & 10 & 10 & 10 & 10 & 10 & 10 & 10 & 10 & 10 & 10 \\
\hline \multicolumn{11}{|l|}{ P401 } \\
\hline Min & -5.54 & -2.08 & -1.93 & -3.49 & -5.32 & -21.10 & -1.51 & -42.92 & -7.24 & -2.15 \\
\hline Max & -2.94 & -1.14 & -1.00 & -1.56 & -2.72 & -20.10 & -1.51 & -40.92 & -6.50 & -1.12 \\
\hline Mean & -4.54 & -1.65 & -1.50 & -2.61 & -4.32 & -20.64 & -1.51 & -41.84 & -6.80 & -1.46 \\
\hline Med & -4.62 & -1.65 & -1.51 & -2.43 & -4.41 & -20.69 & -1.51 & -41.74 & -6.78 & -1.38 \\
\hline SD & 0.83 & 0.36 & 0.35 & 0.72 & 0.83 & 0.33 & 0.00 & 0.66 & 0.25 & 0.36 \\
\hline $\mathrm{CV}$ & -18.28 & -21.56 & -23.52 & -27.70 & -19.21 & -1.61 & 0.00 & -1.59 & -3.60 & -24.61 \\
\hline $\mathrm{N}$ & 8 & 8 & 8 & 8 & 8 & 8 & 8 & 8 & 8 & 8 \\
\hline
\end{tabular}

Legend: $\mathrm{P}=$ Shallow well; $\mathrm{S}=$ Spring; $\mathrm{F}=$ Deep well; Min = Minimum; Max = Maximum; Med = Median; SD = Standard Deviation; CV = Coefficient of Variation; $\mathrm{N}=$ Number of samples.

with Halite and over saturated with the samples of spring S301 and some samples of spring S401 and the Nchi stream (Figure 6). These results indicate that the water-rock interaction had not yet reached its equilibrium point for the surface and ground water of the Foumban locality [32]. The strong under saturation with halite could be attributed to the extreme low concentration of $\mathrm{Cl}^{-}$in the study zone. According to [20] [29], the over saturation with aragonite, calcite and dolomite in S301 could be attributed to silicate weathering and the prolonged residence time in this hydro-system. The SI value obtained in this study 
are similar to those obtained by [24] in Bétaré-Oya gold mining area in the East region of Cameroon and [30] in the urban area of Chongqing in China.

\subsection{Bacteriological Parameters Results}

The bacteriological results are presented in Table 3. Fecal streptococci are almost non-existent in well P401 and spring S301. Meanwhile, they are 30 $\mathrm{CFU} / 100 \mathrm{ml}$ in wells P102, $25 \mathrm{CFU} / 100 \mathrm{ml}$ in spring S401 and $10 \mathrm{CFU} / 100 \mathrm{ml}$ respectively in spring F401 and wells P501 and P504. Fecal Coliforms are also non-existent in well P401 and spring S301 but are considerably present in well P102 with a proportion of $48 \mathrm{CFU} / 100 \mathrm{ml}$, borehole F401 (24 CFU/100 ml), spring S401 (43 CFU/100 ml), wells P501 (19 CFU/100 ml) and P504 (26 CFU/100 ml. Similar to streptococci and coliforms, the presence of Escherichia coli is not detected in wells P401 and spring S301. Meanwhile, they are respectively present in

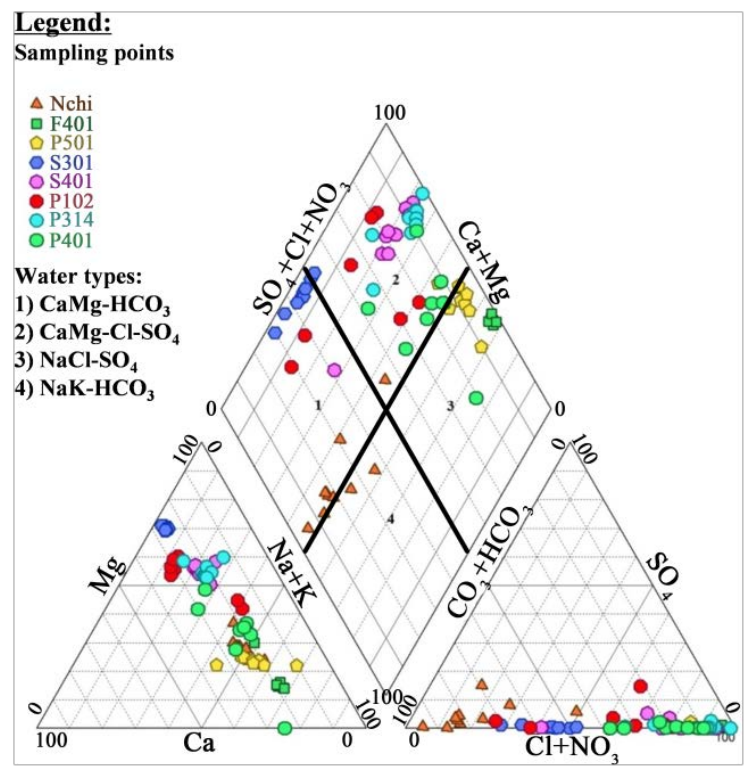

Figure 5. Piper tree-linear diagram for the surface and ground water samples (wells, springs, borehole and Nchi stream) in the study zone.

Table 3. Bacteria counts in the seven analysed samples within the study sites.

\begin{tabular}{cccc}
\hline Samples (CFU/100 ml) & FS (CFU/100 ml) & FC $($ CFU/100 ml $)$ & E. coli $(\mathrm{CFU} / 100 \mathrm{ml})$ \\
\hline P102 & 30 & 48 & 36 \\
S301 & 0 & 0 & 0 \\
P401 & 0 & 0 & 0 \\
F401 & 10 & 24 & 16 \\
S401 & 25 & 43 & 32 \\
P501 & 10 & 19 & 11 \\
P504 & 10 & 26 & 18 \\
WHO Standard & 0 & 0 & 0
\end{tabular}

Legend: $\mathrm{P}=$ shallow well; $\mathrm{S}=$ spring; $\mathrm{F}=$ deep well. 
the following proportions: $36 \mathrm{CFU} / 100 \mathrm{ml}, 16 \mathrm{CFU} / 100 \mathrm{ml}, 32 \mathrm{CFU} / 100 \mathrm{ml}, 11$ $\mathrm{CFU} / 100 \mathrm{ml}$ and $18 \mathrm{CFU} / 100 \mathrm{ml}$ in well P102, borehole F401, spring S401, and wells P501 and P504. These results clearly show that large stands of bacteriological parameters are generally obtained in neighbourhoods with spontaneous habitats characterized by the virtual non-existence of sanitation systems [44] [45]. If the absence of these parameters in well P401 is related to the fact that this structure is regularly maintained, the virtual absence of these parameters in spring S301 is related to the fact that it is not in contact with the atmosphere. Therefore, it would become the outlet for a confined aquifer, as evidenced by the raw hydrochemical data and saturation indices of some minerals that were crystallized in these waters during weathering of rocks.

\subsection{Processes Controlling Water Quality in the Study Area}

To understand the phenomena that govern water quality of the study area, two methods have been implemented: the Gibbs model [40] and the multivariate statistical analysis (MSA).

\subsubsection{Method Based on Gibbs Model}

To identify the contribution of the atmospheric precipitation, rock dominance, and the evaporation-crystallisation processes, TDS versus $\mathrm{Na} /(\mathrm{Na}+\mathrm{Ca})$ or TDS versus $\mathrm{Cl} /\left(\mathrm{Cl}+\mathrm{HCO}_{3}\right)$ are used. In this study, the Gibbs schematic diagram is presented in Figure 7. The diagram reveals that all the samples of well $\mathrm{P} 102$, and the river $\mathrm{Nchi}$ are characterized by low ratios of $\mathrm{Na} /(\mathrm{Na}+\mathrm{Ca})$ and $\mathrm{Cl} /(\mathrm{Cl}+$ $\mathrm{HCO}_{3}$ ) and moderate concentrations of TDS, corresponding specifically to the rock dominance domain. The F401 samples are characterized by high ratios of $\mathrm{Na} /(\mathrm{Na}+\mathrm{Ca})$ and $\mathrm{Cl} /\left(\mathrm{Cl}+\mathrm{HCO}_{3}\right)$ and high concentration of TDS, showing that evaporation and crystallization are the main factors that control water quality. However, other ground water samples of P501, P314, P401 are in an intermediate state, with moderate values of TDS and ratios of $\mathrm{Na} /(\mathrm{Na}+\mathrm{Ca})$ and $\mathrm{Cl} /(\mathrm{Cl}+$ $\left.\mathrm{HCO}_{3}\right)$; they are controlled by rock weathering and evaporation-crystallization processes. The last factor that controls water quality is in accordance with the meteorological data of the study zone, where the evapotranspiration reached about $1200 \mathrm{~mm} /$ year [46] [47] [48].

\subsubsection{Multivariate Statistical Analysis}

\section{1) Correlation matrix}

The correlation matrix (Table 4) shows: weak $(\mathrm{r} \leq 0.5)$, acceptable $(0.5 \leq \mathrm{r} \leq$ $0.7)$, very good $(0.7 \leq \mathrm{r} \leq 0.9)$ correlations between some physico-chemical parameters and bacteriological species. Those relationships between the elements are direct or inverse, depending on whether the correlation coefficient " $r$ " is positive or negative. On the one hand, the very good correlations recorded between certain elements such as: 1) $\mathrm{Ca}^{2+}$ et $\mathrm{Mg}^{2+}, \mathrm{NH}_{4}^{+}, \mathrm{HCO}_{3}^{-}$;2) $\mathrm{Na}^{+}$et $\mathrm{K}^{+}$, $\mathrm{Cl}^{-}, \mathrm{NO}_{3}^{-}, \mathrm{F}^{-}$; 3) $\mathrm{CF}$, SF, et $E$. coli etc. is indicative of their common origin (rocks weathering, leaching of the soil, atmospheric contribution, vegetation and 


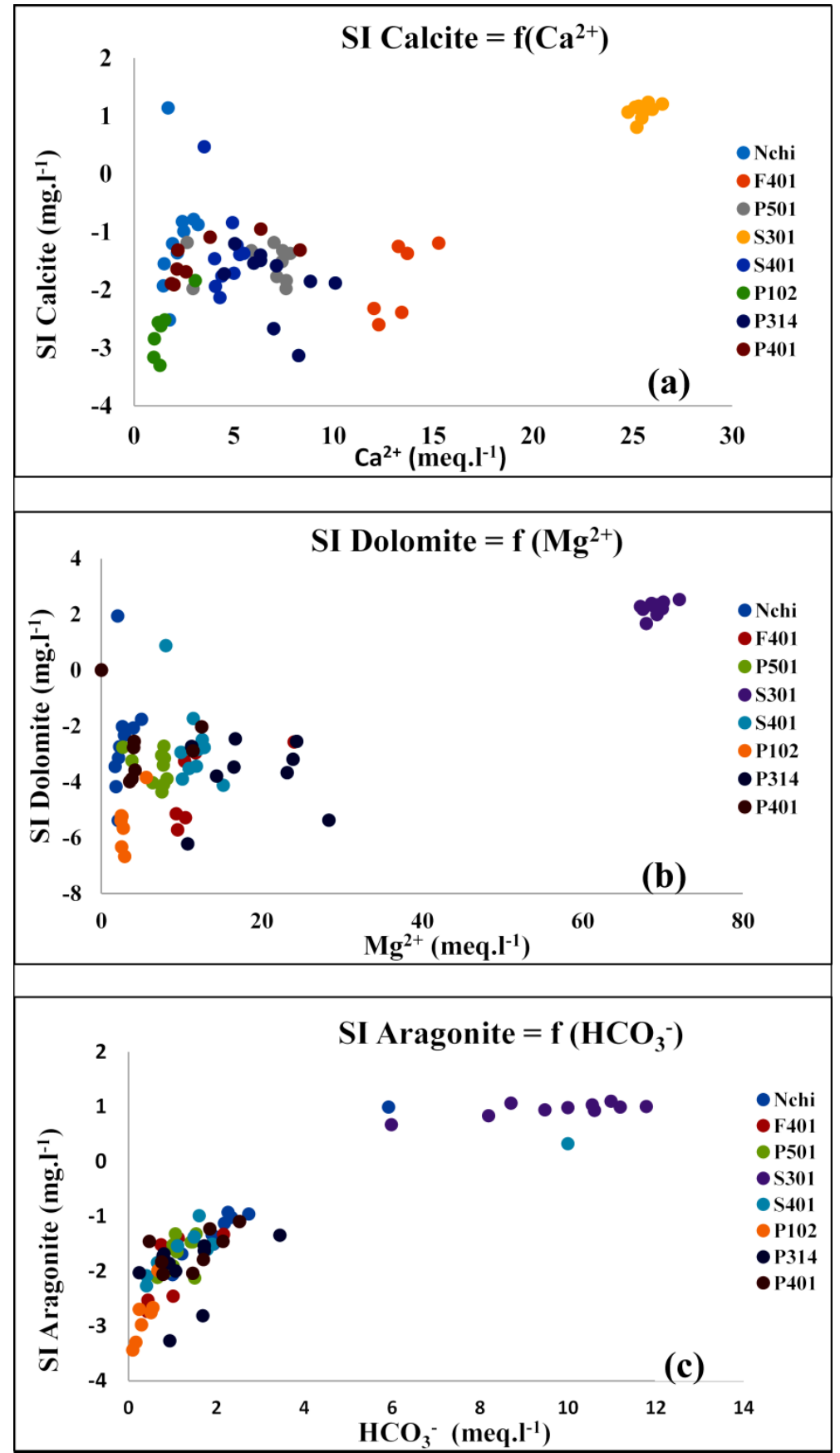

Figure 6. (a) Saturation index (SI) of calcite versus $\mathrm{Ca}^{2+}$; (b) Saturation index of dolomite versus $\mathrm{Mg}^{2+}$ and (c) Saturation index of Aragonite versus $\mathrm{HCO}_{3}^{-}$.

anthropogenic activities). On the other hand, the very good negative correlation observed between the bacteriological parameters (FC, FS and E. coli) and certain hydro-chemical elements (alkalinity, calcium, magnesium, and hydrogen carbonates) are difficult to interpret.

2) Principal component analysis (PCA)

Five factorial axes F1 to F5 are from the ACP. Those factors account for most of the information (80\%) in the data set (Table 5, Figure 8(a)). This is important 
for classifying, studying and validating trends and correlations that may exist between variables and/or labels. The projection of variables and denominations at the factorial level F1-F2 (Figure 8(b)) through the correlation circle shows that:

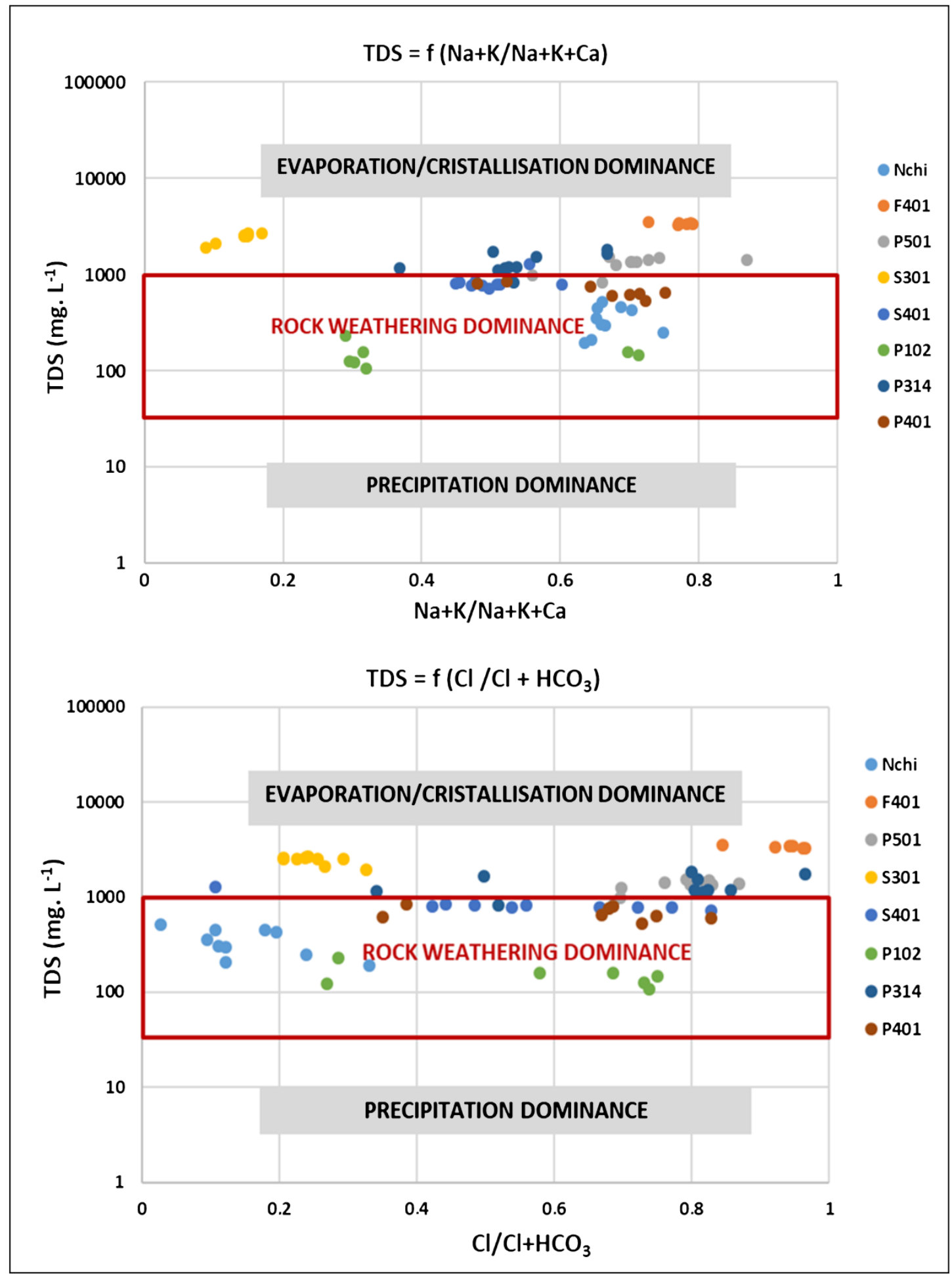

Figure 7. Gibbs diagrams presenting the factor that control the water quality in the study zone. 
Table 4. Pearson's correlation coefficients for physicochemical and bacteriological parameters of water samples.

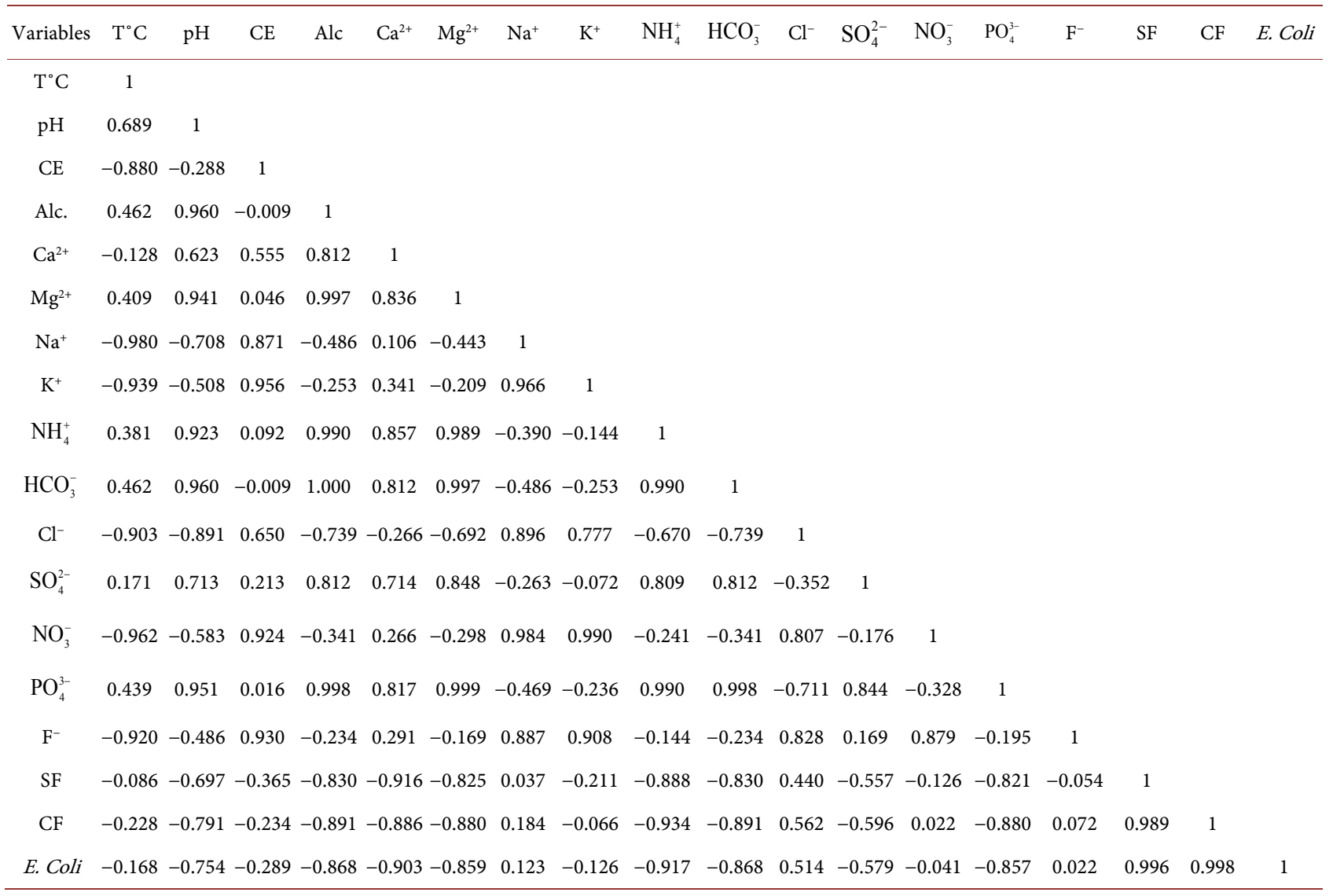

Table 5. Factor loading plots for different principle components.

\begin{tabular}{|c|c|c|c|c|c|}
\hline Parameters & F1 & F2 & F3 & $\mathrm{F} 4$ & F5 \\
\hline $\mathrm{T}^{\circ} \mathrm{C}$ & 0.191 & -0.861 & 0.008 & -0.288 & 0.373 \\
\hline $\mathrm{pH}$ & 0.911 & -0.372 & 0.141 & 0.077 & 0.073 \\
\hline C.E & 0.231 & 0.969 & 0.079 & 0.027 & 0.033 \\
\hline Alc. & 0.979 & -0.016 & 0.179 & 0.081 & 0.054 \\
\hline $\mathrm{Ca}^{2+}$ & 0.772 & 0.499 & -0.048 & 0.384 & -0.069 \\
\hline $\mathrm{Mg}^{2+}$ & 0.931 & 0.089 & 0.308 & 0.113 & 0.136 \\
\hline $\mathrm{Na}^{+}$ & -0.243 & 0.943 & -0.219 & 0.039 & 0.052 \\
\hline $\mathrm{K}^{+}$ & 0.000 & 0.949 & -0.206 & -0.091 & 0.220 \\
\hline $\mathrm{NH}_{4}^{+}$ & 0.983 & 0.064 & 0.043 & -0.165 & 0.034 \\
\hline $\mathrm{HCO}_{3}^{-}$ & 0.979 & -0.016 & 0.179 & 0.081 & 0.054 \\
\hline $\mathrm{Cl}^{-}$ & -0.426 & 0.803 & 0.298 & -0.291 & -0.007 \\
\hline $\mathrm{SO}_{4}^{2-}$ & 0.586 & 0.279 & 0.700 & -0.236 & -0.182 \\
\hline $\mathrm{NO}_{3}^{-}$ & -0.092 & 0.922 & -0.264 & 0.197 & 0.182 \\
\hline $\mathrm{PO}_{4}^{3-}$ & 0.968 & 0.021 & 0.244 & 0.004 & -0.054 \\
\hline $\mathrm{F}^{-}$ & 0.093 & 0.862 & 0.424 & -0.261 & -0.014 \\
\hline SF & -0.674 & -0.157 & 0.703 & 0.159 & 0.044 \\
\hline $\mathrm{CF}$ & -0.714 & -0.026 & 0.665 & 0.204 & 0.083 \\
\hline E. coli & -0.685 & -0.071 & 0.698 & 0.153 & 0.123 \\
\hline
\end{tabular}




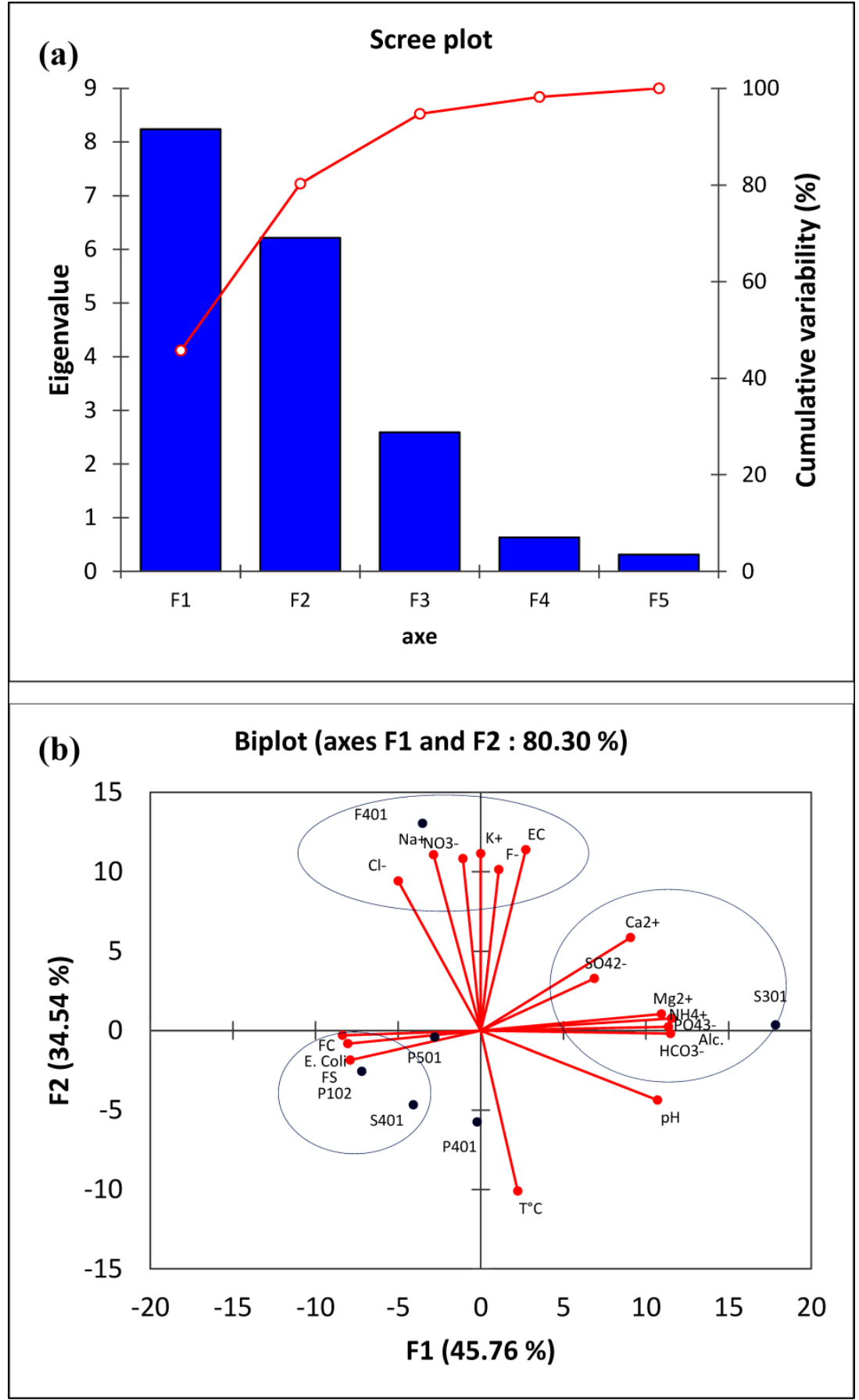

Figure 8. (a) Scree plot; (b) Factors loadings for the F1 and F2.

The F1 factor is the most significant as it controls $45.76 \%$ of cloud inertia of the sample-representative points (Figure 8(b)). It brings together the majority of the variables in the positive pole $\left(\mathrm{HCO}_{3}^{-}, \mathrm{PO}_{4}^{3-} \mathrm{Mg}^{2+}, \mathrm{NH}_{4}^{+}\right.$, and to a lesser extent $\mathrm{Ca}^{2+}$ and $\mathrm{SO}_{4}^{2-}$ ). This pole consists of elements that have a natural/geogenic origin (acid hydrolysis of rock minerals and soil leaching) in water. It can also be seen that at this pole there is spring S301; this position confirms that the water quality of the latter would be much more influenced by the lithological 
nature and soil type (geogenic influence). As such, one might think that this spring is the outlet of a deep aquifer or a fractured aquifer. Its negative pole groups the bacteriological parameters (FC, FS, E. coli) that have an anthropogenic origin. There are water points in this pole, namely: P102, P502, S401 whose quality is much more influenced by anthropogenic inputs. The F2 axis controls $34.54 \%$ of the expressed cloud inertia of the samples representative points. It also brings together variables such as: $\mathrm{Cl}^{-}, \mathrm{Na}^{+}, \mathrm{NO}_{3}^{-}, \mathrm{CE}, \mathrm{K}^{+}$and $\mathrm{F}^{-}$which have a mixed origin, i.e. may come from anthropogenic activities, weathering and atmospheric inputs. Borehole F401 is found in this pole where water quality is highly influenced by anthropogenic inputs (presence of bacterial colonies) and nature of rocks.

\section{3) Hierarchical clustering analysis (HCA)}

The hierarchical analysis suggests two mains clusters, Cluster I and cluster II. The first is made up of spring S301. This position perfectly illustrates the particularity of this spring, the plausible interpretation could be that it discharges from a fractured aquifer or a captive aquifer, unlike spring S401, which would rather be the outlet of the alterites or subsurface aquifer. Cluster II is subdivided into two other clusters: cluster II-A and cluster II-B. The first includes borehole F401; this position suggests that this borehole would capture two aquifers, including the deep fractured aquifer and the subsurface aquifer. The layout of spring S301 and borehole F401 on the dendrogram is in perfect harmony with the values of mineral oversaturation indices such as Aragonite, Calcite and Water Dolomite from waters of spring S301. Finally, Cluster II-B consists of wells (P102, P501, P314 and 401) spring (S401), and the Nchi stream. This grouping confirms the perfect hydraulic relationship that would exist between these hydrosystems. In general, it should be noted that the distribution of hydraulic structures (wells, springs and Nchi streams) on this dendrogram (Figure 9) confirms the complex and heterogeneous nature of underground and surface hydrosystems in the basement milieu [20] [21] [49].

Information from the MSA (correlation matrix, factor circles and dendrogram) shows that the water quality of the study area is influenced by two main factors, the nature of geological substratum and by hydrolysis of minerals and rocks, soil leaching and anthropogenic origin (low level of sanitation, lack of hygiene...) [5] [49] [50]. The variation in concentrations of these physico-chemical parameters and in particular that of nitrates would account for the diversity of hydrogeochemical facies of the study area. The HCA through Figure 9 reflects the complexity of the functioning of underground and surface hydro-systems from the point of view of water quality and the necessity to consider them even at the scale of a small hydrogeological unit as a mosaic of small systems independent of one another.

\subsection{Hydrogeochemical Conceptual Model for Surface and Groundwater}

According to the water quality characteristic, the hydro-geochemical modelling 


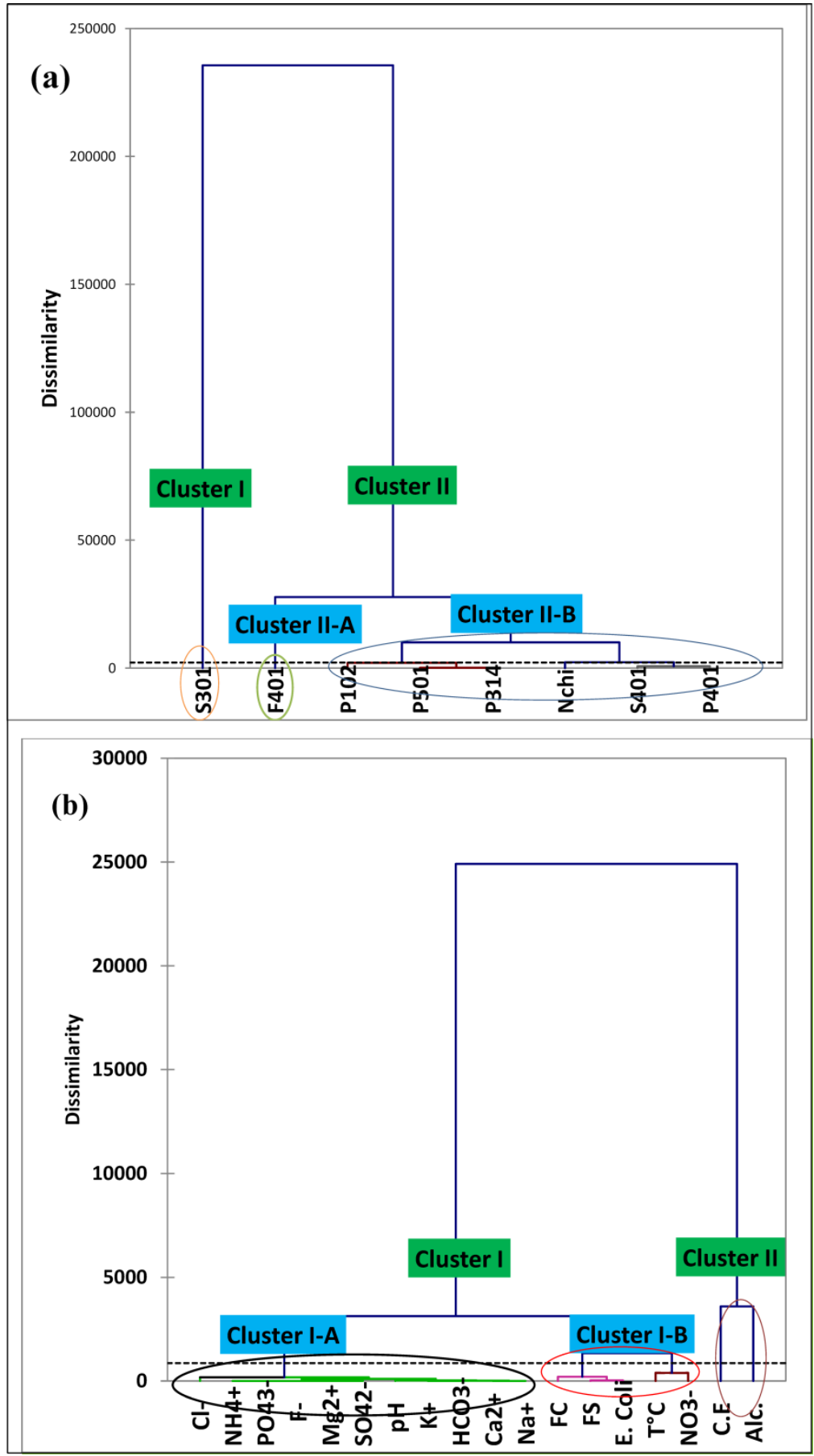

Figure 9. Dendrograms showing: (a) the hierarchical clusters of analysed samples site (b) analysed parameters.

(water types, saturation indices, Gibbs model) and multivariate statistical analysis (PCA and HCA), the complexity of the chemical and bacteriological characteristics of surface and ground water functioning in the crystalline basement milieu can be illustrated by the conceptual model of data presented in Figure 10 . This complexity has also been highlighted by [16] [51] using hydrodynamic characteristics of aquifers. This complexity is manifest through the fact that a 


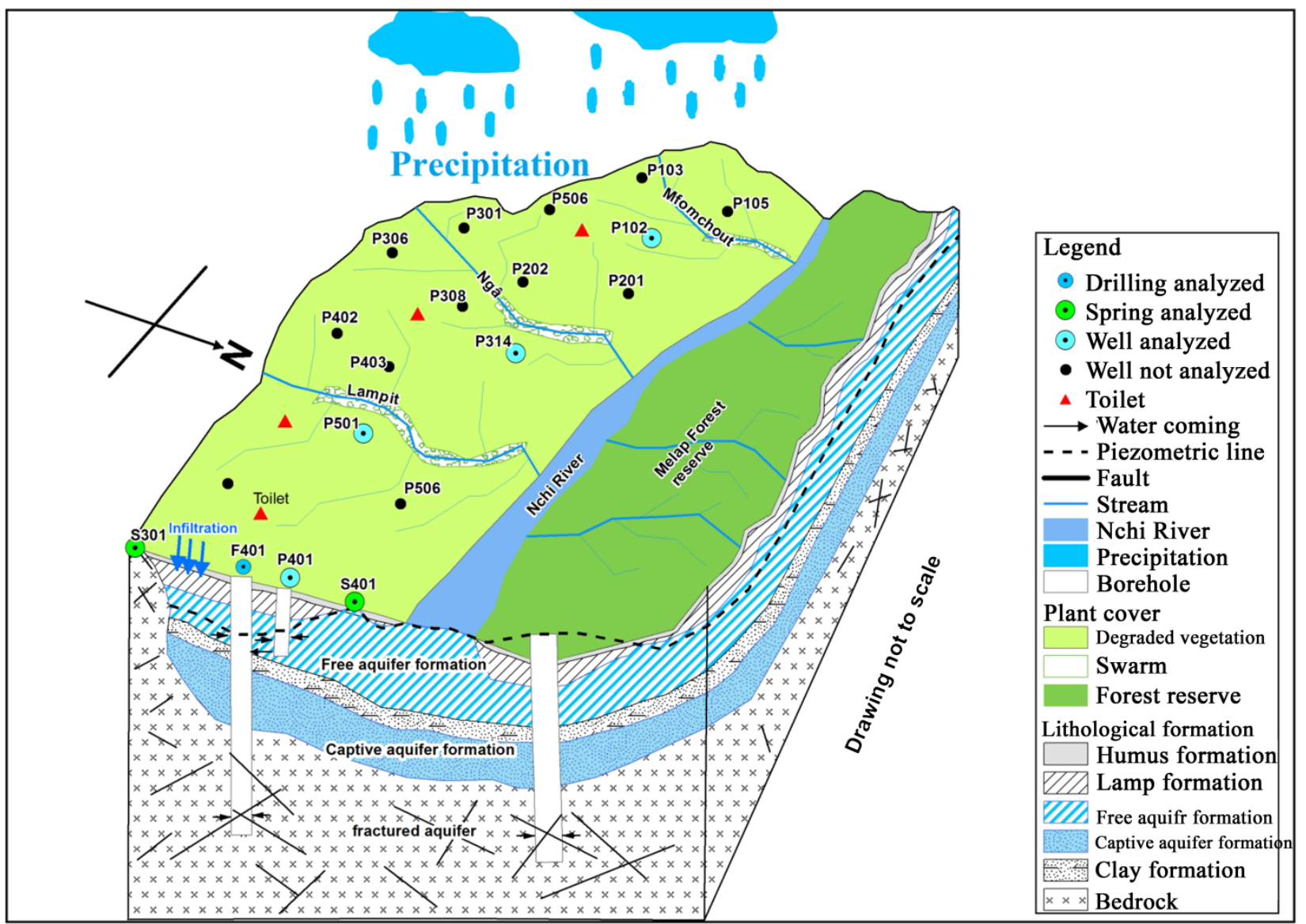

Figure 10. Hydro-geochemical conceptual model of natural water system in the Foumban locality in the crystalline and christallophylian basement milieu.

single type of structure such as wells or springs can capture different aquifers in the basement milieu and in a small geographical area; this is the case for example of springs S301 and S401.

\section{Conclusions}

Assessment of surface and ground water based on standard hydrochemical analysis, hydrogeochemical modelling and multivariate statistical analyses served as an important exploratory tool to analyse and interpret the complex and various data set. The characteristics of surface and ground water quality resources in the Bamoun plateau, specifically in the Foumban locality can be summarized as follows:

1) Surface water and ground water in this studied zone are acid to basic (4.50 $\leq \mathrm{pH} \leq 8.48)$, very weakly to weakly mineralized $(8.40 \leq \mathrm{EC} \leq 398.00 \mu \mathrm{S} / \mathrm{cm})$ with four main water types: $\mathrm{CaMg}-\mathrm{HCO}_{3}, \mathrm{CaMg}-\mathrm{Cl}-\mathrm{SO}_{4}, \mathrm{NaCl}-\mathrm{SO}_{4}$ and $\mathrm{NaK}-$ $\mathrm{HCO}_{3}^{-}$;

2) The major elements were all within the World Health Organization (WHO) guidelines for drinking water quality, except for nitrates in borehole F401 which was found at a concentration $>50 \mathrm{mg} \quad \mathrm{NO}_{3}^{-} / \mathrm{l}$. For the hydrobiological aspect, all 
the samples contained the bacteriological species except for the spring S301 and well P401;

3) The Gibbs model, the saturation index, and the multivariate statistical analysis show that the surface and ground water quality of this locality are influenced by two main factors: a) the natural factor which include the water-rock interaction, soil leaching, precipitation/dissolution of minerals, evaporation/crystallization. The distribution of ionic ratio (SI calcite versus $\mathrm{Ca}^{2+}$; $\mathrm{Si}$ dolomite versus $\mathrm{Mg}^{2+}$ and SI aragonite versus $\mathrm{HCO}_{3}^{-}$) show that the water-rock interaction had not yet reached its equilibrium in the surface and ground water of the study zone; b) the anthropogenic factors such as: uncontrolled discharges of liquid and solid effluents of all kinds and without any prior treatment within the ground and the strong urbanization accompanied by a lack of sanitation and insufficient care.

4) The ion concentrations in the Nchi stream and ground water (springs, wells and borehole) to a certain degree overlap. This indicates the presence of different supply connections or not between them in different sector of the study zone. Those different connections based on the results of geochemical and bacteriological characteristic illustrate the complexity of those hydro-systems which functions as a mosaic of microsystems independent from one another at the watershed-scale.

\section{Acknowledgements}

The authors thank the PAFROID educational grant program "Number HDP2A", UNESCO through ANESI scholarships programs, Laboratory of Mineral Resources and Environment of the Department of Geology, Faculty of Science of the University of Tunis El Manar, Tunisia. Thanks are also extended to the Editor in Chief of the Journal of Water Resource and Protection, and the anonymous reviewers who helped in improving the quality of the manuscript.

\section{Conflicts of Interest}

The authors declare no conflicts of interest regarding the publication of this paper.

\section{References}

[1] Rakotondrabe, F., Ndam Ngoupayou, J.R., Mfonka, Z., Rasolomanana, E.H., Nyangono Abolo, A.J. and Ako Ako, A. (2018) Water Quality Assessment in the BétaréOya Gold Mining Area (East-Cameroon): Multivariate Statistical Analysis Approach. Science of the Total Environment, 610, 831-844. https://doi.org/10.1016/j.scitotenv.2017.08.080

[2] Owoyemi, F.B., Oteze, G.E. and Omonona, O.V. (2019) Spatial Patterns, Geochemical Evolution and Quality of Groundwater in Delta State, Niger Delta, Nigeria: Implication for Groundwater Management. Environment Monitoring and Assessment, 191, 617. https://doi.org/10.1007/s10661-019-7788-2

[3] Reinaldy Pratama, P., Tjahyo Nugroho, A., Langgeng Wahyu, S. and Nurul, K. (2020) 
Hydrogeochemical Conditions in Groundwater Systems with Various Geomorphological Units in Kulonprogo Regency, Java Island, Indonesia. Aquatic Geochemistry, 26, 421-454.

[4] Sanjoy, S., Umesh Kumar, S. and Pankaj, M. (2019) Water Quality Assessment of a Tropical River Using Water Quality Index (WQI), Multivariate Statistical Techniques and GIS. Applied Water Science, 9, 168.

https://doi.org/10.1007/s13201-019-1045-2

[5] Liu, J.T., et al. (2019) Hydrochemical Characteristics and Quality Assessment of Groundwater for Drinking and Irrigation Purposes in the Futuan River Basin, China. Arabian Journal of Geosciences, 12, 560.

https://doi.org/10.1007/s12517-019-4732-2

[6] Mfonka, Z. (2019) Hydrodynamique et vulnérabilité des nappes en zone de socle fissuré et al téré: Cas de la localité de Foumban dans le bassin versant du Nchi (Ouest-Cameroun). PhD Dissertation, University of Yaoundé 1, Yaoundé, 289.

[7] Okomo Atouba, L.C., Chazot, G., Moundi, A., Agranier, A., Bellon, H., Nonnotte, P., Nzenti, J.-P. and Kankeu, B. (2016) Mantle Sources beneath the Cameroon Volcanic Line: Geochemistry and Geochronology of the Bamoun Plateau Mafic Rocks. Arabian Journal of Geosciences, 9, 1-12.

https://doi.org/10.1007/s12517-015-2285-6

[8] Ziem, A., Bidias, L.A., Chazot, G., Moundi, A. and Nonnotte, P. (2018) Extreme Source Heterogeneity and Complex Contamination Patterns along the Cameroon Volcanic Line: New Geochemical Data from the Bamoun Plateau. Compte Rendu de Géosciences, 350, 100-109. https://doi.org/10.1016/j.crte.2017.11.004

[9] Mfonka, Z., Ndam Ngoupayou, J.R., Ndjigui, P.-D., Kpoumié, A., Zammouri, M., Ngouh, A.N., Mouncherou, O.F., Rakotondrabe, F. and Rasolomanana, E.H. (2018) A GIS-Based DRASTIC and GOD Models for Assessing Alterites Aquifer of Three Experimental Watersheds in Foumban (Western-Cameroon). Groundwater and Sustainable Development, 7, 250-264. https://doi.org/10.1016/j.gsd.2018.06.006

[10] Ngo'o Ze, A., Onana, V.L., Ndzié Mvindi, A.T., Nyassa Ohandja, H., Medjo Eko, R. and Ekodeck, G.E. (2019) Variability of Geotechnical Parameters of Lateritic Gravels Overlying Contrasted Metamorphic Rocks in a Tropical Humid Area (Cameroon) Implications for Road Construction. Bulletin of Engineering Geology and Environment, 78, 5531-5549. https://doi.org/10.1007/s10064-019-01488-0

[11] Hajji, S., Nasri, G., Boughariou, E., Bahloul, M., Allouche, N. and Bouri, S. (2020) Towards Understanding Groundwater Quality Using Hydrochemical and Statistical Approaches: Case of Shallow Aquifer of Mahdia-Ksour Essaf (Sahel of Tunisia). Environmental Science and Pollution Resources, 27, 5251-5265. https://doi.org/10.1007/s11356-019-06982-2

[12] Olivry, J.C. (1986) Fleuves et rivières du Cameroun. MESRES-ORSTOM, monographie hydrologique, Paris, 733.

[13] Weeksteen (1957) Carte géologique de reconnaissance au 1/500000, feuille DoualaEst avec Notice explicative. Direction des Mines et de la Geology, Cameroun, 35.

[14] Moundi, A., Wandji, P., Bardintzeff, J.M., Ménard, J.J., Okomo Atouba, L.C., Mouncharou, O.F., Reusser, E., Bellon, H. and Tchoua, F. (2007) Les basaltes éocènes à affinité transitionnelle du plateau Bamoun, témoins d'un réservoir mantellique enrichi sous la ligne volcanique du Cameroun. Compte Rendu de Géosciences, 339, 396-406. https://doi.org/10.1016/j.crte.2007.04.001

[15] Tchakounté, J., Eglinger, A., Toteu, S.F., Zeh, A., Nkoumbou, C., Mvondo Ondoa, J., Penaye, J., de Wit, M. and Barbey, P. (2017) The Adamawa-Yadé Domain, a Piece 
of Archaean Crust in the Neoproterozoic Central African Orogenic Belt (Bafia Area, Cameroon). Precambrian Research, 299, 210-229. https://doi.org/10.1016/j.precamres.2017.07.001

[16] Mfonka, Z., Ndam Ngoupayou, J.R., Kpoumie, A., Ndjigui, P.-D., Zammouri, M. Ngouh, A.N., Mouncherou, O.F., Mfochivé, O.F. and Rakotondrabe, F. (2019) Hydrodynamic and Groundwater Vulnerability Assessment of the Shallow Aquifer of the Foumban Locality (Bamoun Plateau, Western-Cameroon). Arabian Journal of Geosciences, 12, 165. https://doi.org/10.1007/s12517-019-4328-x

[17] Djeuda Tchapnga, H.B., Ngo Massana, B., Siakeu, J., Tanawa, E. and Temgoua, E. (1999) Modèles de circulation, mécanisme de recharge, et temps de séjour des eaux souterraines des altérites en milieu cristallin: Cas du bassin versant de l'Anga'a, Yaoundé-Cameroun. Collect GIOCAM 2/1999, Ed Sci: VICAT JP, BILONG P, Ed Presses Univ de Ydé, 117-126.

[18] Lachassagne, P., Wyns, R. and Dewandel, B. (2011) The Fracture Permeability of Hard Rock Aquifers Is Due Neither to Tectonics, Nor to Unloading, But to Weathering Processes. Terra Nova, 10, 1365-3121. https://doi.org/10.1111/j.1365-3121.2011.00998.x

[19] Lachassagne, P., Dewandel, B. and Wyns, R. (2015) The Conceptual Model of Hard Rock Aquifers and Its Practical Applications. Vingtièmes journées techniques du Comité Français d'Hydrogéologie de l'Association Internationale des Hydrogéologues. La Roche-sur-Yon. 11. https://doi.org/10.1201/b17016-3

[20] Charlier, J.-B., Lachassagne, P., Ladouche, B., Cattan, P., Moussa, R. and Voltz, M. (2011) Structure and Hydrogeological Functioning of an Insular Tropical Humid Andesitic Volcanic Watershed: A Multi-Disciplinary Experimental Approach. Journal of Hydrology, 398, 155-170. https://doi.org/10.1016/j.jhydrol.2010.10.006

[21] Guihéneuf, N., Boisson, A., Bour, O., Dewandel, B., Perrin, J., Dausse, A., Viossanges, M., Chandra, S., Ahmed, S. and Maréchal, J.C. (2014) Groundwater Flows in Weathered Crystalline Rocks: Impact of Piezometric Variations and Depth Dependent Fracture Connectivity. Journal of Hydrology, 511, 320-334. https://doi.org/10.1016/j.jhydrol.2014.01.061

[22] Rodier, J. (2009) Analyse de l'eau. Dunod, 9th Edition, Paris, 1579.

[23] Mfonka, Z., Ndam Ngoupayou, J.R., Ndjigui, P.-D., Zammouri, M., Kpoumie, A. and Rasolonana, E. (2015) Hydrochimie et potabilité des eaux du bassin versant du Nchi dans le plateau Bamoun (Ouest Cameroun). International Journal of Biological and Chemical Sciences, 9, 2000-2018. https://doi.org/10.4314/ijbcs.v9i4.39

[24] Rakotondrabe, F., Ndam Ngoupayou, J.R., Mfonka, Z., Rasolomanana, E.H., Nyangono Abolo, A.J., Banakeng, L.A., Ako Ako, A. and Rakotondrabe, M.H. (2017) Assessment of Surface Water Quality of Bétaré-Oya Gold Mining Area (East-Cameroon). Journal of Water Resource and Protection, 9, 960-984.

https://doi.org/10.4236/jwarp.2017.98064

[25] Khosravi, R., Zarei, M. and Bigalke, M. (2018) Characterizing Major Controls on Spatial and Seasonal Variations in Chemical Composition of Surface and Pore Brine of Maharlu Lake, Southern Iran. Aquatic Geochemistry, 24, 27-54. https://doi.org/10.1007/s10498-018-9329-y

[26] Hosseini, H., Shakeri, A., Rezaei, M., Dashti Barmaki, M. and Rastegari Mehr, M. (2020) Water Chemistry and Water Quality Pollution Indices of Heavy Metals: A Case Study of Chahnimeh Water Reservoirs, Southeast of Iran. International Journal of Energy and Water Resource, 4, 63-79. https://doi.org/10.1007/s42108-019-00051-7 
[27] Akrong, M., Amu Mensah, F., Amu Mensah, M., Darko, H., Addico, G. and Ampofo, J. (2019) Seasonal Analysis of Bacteriological Quality of Drinking Water Sources in Communities Surrounding Lake Bosomtwe in the Ashanti Region of Ghana. Applied Water Science, 9, 82. https://doi.org/10.1007/s13201-019-0959-Z

[28] Wali, S.U., Jega, U.K., Sheikh Danjuma, A., Ifabiyi Ifatokun, P., Dankani, I.M., Shera, I.M. and Garba Yauri, S. (2019) Hydrochemical Characterization of Shallow and Deep Groundwater in Basement Complex Areas of Southern Kebbi State, Sokoto Basin, Nigeria. Applied Water Science, 9, 169.

https://doi.org/10.1007/s13201-019-1042-5

[29] Singh, C.K., Anand, K., Shashtri, S., Alok, K., Pankaj, K. and Mallick, J. (2017) Multivariate Statistical Analysis and Geochemical Modeling for Geochemical Assessment of Groundwater of Delhi, India. Journal of Geochemical Exploration, 175, 59-71. https://doi.org/10.1016/j.gexplo.2017.01.001

[30] Yang, P., Cheng, Q., Xie, S., Wang, J., Chang, J., Yu, Q., Zhan, Z. and Chen, F. (2017) Hydrogeochemistry and Geothermometry of Deep Thermal Water in the Carbonate Formation in the Main Urban Area of Chongqing, China. Journal of $\mathrm{Hy}^{-}$ drology, 549, 50-61. https://doi.org/10.1016/j.jhydrol.2017.03.054

[31] Kim, J.H., Kim, R.H., Lee, J. and Chang, H.W. (2003) Hydrogeochemical Characterization of Major Factors Affecting the Quality of Shallow Groundwater in the Coastal Area at Kimje in South Korea. Environmental Geology, 44, 478-489. https://doi.org/10.1007/s00254-003-0782-5

[32] Zhang, Y., Xu, M., Li, X., Qi, J., Zhang, Q., Guo, J., Yu, L. and Zhao, R. (2018) Hydrochemical Characteristics and Multivariate Statistical Analysis of Natural Water System: A Case Study in Kangding County, Southwestern China. Water, 10, 80. https://doi.org/10.3390/w10010080

[33] Shawgar, K., Mohammad, J., Homayoon, K. and Ahmadn, F.M. (2020) Groundwater Hydrogeochemical Assessment Using Advanced Spatial Statistics Methods: A Case Study of Tehran-Karaj Plain Aquifer, Iran. Arabian Journal of Geosciences, 13, 84. https://doi.org/10.1007/s12517-019-5047-Z

[34] Pawan, K., Ambrish, K. and Mahajan Anil, K. (2020) Groundwater Geochemical facie: Implications of Rock-Water Interaction at the Chamba City (HP), Northwest Himalaya, India. Environmental Science and Pollution Research, 27, 9012-9026. https://doi.org/10.1007/s11356-019-07078-7

[35] Everitt, B.S. and Hothorn, T. (2011) An Introduction to Applied Multivariate Analysis with R. Springer, New York.

[36] Roques, C., Aquilina, L., Bour, O., Maréchal, J.-C., Dewandel, B., Pauwels, H., Labasque, T. and Vergnaud-Ayraud, V. (2014) Groundwater Sources and Geochemical Processes in a Crystalline Fault Aquifer. Journal of Hydrology, 519, 3110-3128. https://doi.org/10.1016/j.jhydrol.2014.10.052

[37] Cloutier, V., Lefebvre, R., Therrien, R. and Savard, M.M. (2008) Multivariate Statistical Analysis of Geochemical Data as Indicative of the Hydrogeochemical Evolution of Groundwater in a Sedimentary Rock Aquifer System. Journal of Hydrology, 353, 294-313. https://doi.org/10.1016/j.jhydrol.2008.02.015

[38] Tanasković, I., Golobocanin, D. and Miljević, N. (2012) Multivariate Statistical Analysis of Hydrochemical and Radiological Data of Serbian Spa Waters. Journal of Geochemical Exploration, 112, 226-234. https://doi.org/10.1016/j.gexplo.2011.08.014

[39] Matiatos, I., Alexopoulos, A. and Godelitsas, A. (2014) Multivariate Statistical Analysis of the Hydrogeochemical and Isotopic Composition of the Groundwater Re- 
sources in Northeastern Peloponnesus (Greece). Science of the Total Environment, 476, 577-590. https://doi.org/10.1016/j.scitotenv.2014.01.042

[40] Gibbs, R.J. (1970) Mechanisms Controlling World Water Chemistry. Science, 17, 1088-1090. https://doi.org/10.1126/science.170.3962.1088

[41] Detay, M. (1993) Le forage d'eau, réalisation, entretien, réhabilitation. Masson, Paris, 375.

[42] Boeglin, J.L., Ndam Ngoupayou, J.R. and Braun, J.J. (2003) Composition of the Different Reservoir Waters in a Tropical Humid Area: Example of the Nsimi Catchment (Southern Cameroon). Journal of African Earth Science, 37, 103-110. https://doi.org/10.1016/S0899-5362(03)00041-1

[43] Piper, A.M. (1944) A Graphic Procedure in the Geochemical Interpretation of Water-Analyses. EOS, Transactions American Geophysical Union, 25, 914-928. https://doi.org/10.1029/TR025i006p00914

[44] Tiodjio, E.R., Fantong, Y.W., Tchakam Kamtchueng, B., Tanyileke, G., Takeshi, O., Hell, J.V., Kusakabe, M., Nakamura, S. and Ueda, A. (2015) Bacteriological Assessment of Drinking Water Sources in the Vicinities of Lakes Nyos and Monoun (Cameroon, Central Africa). Journal of Environmental Science and Water Resource, 4 , 60-70. https://doi.org/10.1038/srep06151

[45] Kringel, R., Rechenburg, A., Kuitcha, D., Fouépé, A., Bellenberg, S., Kengne, I.M. and Fomo, M.A. (2017) Mass Balance of Nitrogen and Potassium in Urban Groundwater in Central Africa, Yaounde/Cameroon. Science of the Total Environment, 547, 382-395. https://doi.org/10.1016/j.scitotenv.2015.12.090

[46] Xing, L., Guo, H. and Zhan, Y. (2013) Groundwater Hydrochemical Characteristics and Processes along Flow Paths in the North China Plain. Journal of Asian Earth Science, 70, 250-264. https://doi.org/10.1016/j.jseaes.2013.03.017

[47] Nguyen, T.T., Kawamura, A., Tong, T.N., Nakagawa, N. and Gilbuenan, J.R. (2014) Hydrogeochemical Characteristics of Groundwater from the Two Main Aquifers in the Red River Delta, Vietnam. Journal of Asian Earth Science, 93, 180-192. https://doi.org/10.1016/j.jseaes.2014.07.035

[48] Ghouili, N., Hamzaoui-Azaza, F., Zammouri, M., Zaghrarni, M.F., Horriche, F.J. and Condesso de Melo, M.T. (2018) Groundwater Quality Assessment of the Takelsa Phreatic Aquifer (Northeastern Tunisia) Using Geochemical and Statistical Methods: Implications for Aquifer Management and End-Users. Environmental Science and Pollution Research, 25, 36306-36327.

https://doi.org/10.1007/s11356-018-3473-1

[49] Zghibi, A., Merzougui, A., Zouhri, L. and Tarhouni, J. (2014) Understanding Groundwater Chemistry Using Multivariate Statistics Techniques to the Study of Contamination in the Korba Unconfined Aquifer System of Cap-Bon (North-East of Tunisia). Journal of African Earth Science, 89, 1-15. https://doi.org/10.1016/j.jafrearsci.2013.09.004

[50] Chihi, H., de Marsily, G., Belayouni, H. and Yahyaoui, H. (2015) Relationship between Tectonic Structures and Hydrogeochemical Compartmentalization in Aquifers: Example of the "Jeffara de Medenine" System, South-East Tunisia. Journal of Hydrology: Regional Studies, 4, 410-430. https://doi.org/10.1016/j.ejrh.2015.07.004

[51] Dewandel, B., Lachassagne, P., Wyns, R., Marechal, J.C. and Krishnamurthy, N.S. (2006) A Generalized 3-D Geological and Hydrogeological Conceptual Model of Granite Aquifers Controlled by Single or Multiphase Weathering. Hydrology Journal, 330, 260-284. https://doi.org/10.1016/j.jhydrol.2006.03.026 